\title{
Invasive submerged macrophytes complicate management of a shallow boreal lake: a 42-year history of monitoring and restoration attempts in Littoistenjärvi, SW Finland
}

\author{
Jouko Sarvala $(\mathbb{D} \cdot$ Harri Helminen · Jukka Heikkilä
}

Received: 1 November 2019/Revised: 5 May 2020/Accepted: 29 May 2020/Published online: 9 June 2020

(c) The Author(s) 2020

\begin{abstract}
The small, shallow lake Littoistenjärvi (SW Finland) experienced in 1978-2019 rapid fluctuations between extreme ecological states, initially associated with mass occurrences of the submerged macrophyte Elodea canadensis Michx. In collapse years following abundance peaks, water was turbid, in other years clear. Aeration prevented anoxia under icecover, but this favoured Elodea. Mechanical plant removal accelerated Elodea growth, and had to be abandoned. Recurrent cyanobacterial blooms started in 2000, and by 2006 phosphorus and chlorophyll reached new high levels because of increased internal loading. During this turbid state, internal loading showed significant positive correlation with maximum water temperature and $\mathrm{pH}$. External loading was
\end{abstract}

Guest editors: Tom Jilbert, Raoul-Marie Couture, Brian J. Huser \& Kalevi Salonen / Restoration of eutrophic lakes: current practices and future challenges.

J. Sarvala $(\bowtie)$

Department of Biology, University of Turku,

20014 Turku, Finland

e-mail: jouko.sarvala@utu.fi

H. Helminen

Centre for Economic Development, Transport and the

Environment for Southwest Finland, Turku, Finland

\section{J. Heikkilä}

Department of Management and Entrepreneurship, Turku School of Economics, University of Turku, 20014 Turku, Finland reduced in 2011 by one-third by diverting runoff from a former arable field transformed into a wetland. Precipitation of phosphorus with polyaluminium chloride in 2017 restored the clear-water state. The case of Littoistenjärvi shows that if internal loading has become the major factor controlling water quality, traditional restoration methods (external load reduction, aeration, removal fishing) provide limited possibilities to improve water quality. Instead, chemical precipitation of phosphorus seems a promising measure which can break the vicious circle of algal blooms and internal loading. Unfortunately, the uncontrollable growth of invasive submerged macrophytes may jeopardise the positive development.

Keywords Elodea -Aluminium chloride - Chemical restoration - Alternative stable states - Regime shift . Lake restoration

\section{Introduction}

Eutrophication of lakes caused by too high external nutrient loading is a common problem all over the world (Zamparas \& Zacharias, 2014), being small and shallow urban lakes particularly vulnerable (Huser et al., 2016b). The deterioration of water quality restricts the uses of lakes for water supply and reduces their value for humans, creating a need for restoration 
(Jeppesen et al., 2017). The reduction of external loading is the primary remedy (Jeppesen et al., 2005; Hamilton et al., 2016), but is often difficult to implement, and does not always lead to fast recovery. In many lakes the internal loading - the flux of nutrients into water from the huge storage accumulated in the bottom sediment during the lake's history-maintains the high nutrient levels (Marsden, 1989; Søndergaard et al., 2013). The numerous causes and mechanisms of internal loading are not all well understood, and the restoration of a good ecological state in internally loaded lakes is a process which may take a long time, often several decades (Sas, 1990; Jeppesen et al., 2007; Steinman \& Spears, 2020). To speed up this change, several restoration methods have been applied, such as oxygenation or biomanipulation (Hansson et al., 1998; Jeppesen et al., 2012; Salmi et al., 2014), but these have not always been successful. The potential of oxygenation in lake restoration has been lately challenged (e.g. Hupfer \& Lewandowsky, 2008; Niemistö et al., this issue), and in the case of biomanipulation, even when water quality has improved, return to the turbid conditions has often followed after some 8-10 years (Søndergaard et al., 2007). In the search of more efficient restoration measures, chemical precipitation of phosphorus has been tested several times in the past (Cooke et al., 2005; Mackay et al., 2015; Araujo et al., 2016; Huser et al., 2016a). Among chemical precipitation methods (Jančula \& Maršálek, 2011), aluminium chloride is perhaps the most often used precipitant (Huser et al., 2016a). The chemical treatment produces immediate results, but the longevity of the good water quality has been variable, from 1 to 2 years to several decades (Huser et al., 2016a). The factors affecting the success of the various restoration measures are only partially known. Well-documented case studies of applications of different methods are therefore still valuable.

Although $85 \%$ of the lake area in Finland is in good or excellent ecological state according to the EU Water Framework Directive, many of the small, shallow lakes particularly in southwestern parts of the country have become eutrophicated during recent decades, resulting in poor or even bad ecological status. One such badly deteriorated small lake is Littoistenjärvi in southwest Finland. Over the last four decades, Littoistenjärvi has experienced rapid fluctuations between extreme ecological states. Such rapid changes are common in eutrophic lakes, and have been theoretically analysed as regime shifts between alternative stable states (e.g. Scheffer et al., 1993, Scheffer $\&$ van Nes, 2007; Wang et al., 2012). These can arise from internal dynamics, but in freshwater ecosystems increasingly often the cause is external pressure (e.g. long-term excessive nutrient loading and gradual climate change, or short-term extreme weather events) (Spears et al., 2016). Although recent critical reviews indicate that there is little robust evidence of real regime shifts in nature (Capon et al., 2015), in some systems the dynamics of invasive species can induce abrupt changes resembling regime shifts (Hilt et al., 2018).

There is thus an urgent need of empirical evidence to improve the understanding of the causes of such ecological instability in eutrophic lakes (Spears et al., 2016), and in particular the role of invasive species in forcing such changes. This article summarises and analyses the information about the restoration of a eutrophic Finnish lake gathered during more than four decades, constituting a relevant example of the variable success of different restoration measures applicable in shallow eutrophic lakes, and of the crucial importance of the invasive macrophytes in aquatic ecosystems.

\section{Study lake}

Littoistenjärvi $\left(60^{\circ} 27^{\prime} \mathrm{N}, 22^{\circ} 24^{\prime} \mathrm{E}\right)$ has a drainage area of $3.9 \mathrm{~km}^{2}$, a surface area of $1.5 \mathrm{~km}^{2}$, average depth of $2.2 \mathrm{~m}$ and volume of $3.25 \mathrm{Mm}^{3}$ with 1.8 -year residence time of water (Fig. 1). Before the twentieth century, there were few houses and little human activity in the catchment, and the external loading of the lake remained at pristine levels. Lake water was used for clothing fabric manufacturing in 1739-1969, and to maintain the water quality, the sewage was discharged to the outlet below the lake. Human population in the neighbourhood of the lake increased rapidly in the 1900s. The first buildings were mainly holiday homes, but the construction of residential houses activated in the 1950s. The number of inhabitants in the Littoinen village rose from 686 in 1925 to 6100 in 1993, but a major part of the settlements were located outside the catchment. From 1903 to the 1930s, the lake received wastewater from at first a laundry, then a brewery, and in 1919-1931 a cannery for vegetables, fish and meat at the lake. There was little agriculture in the Littoistenjärvi catchment 


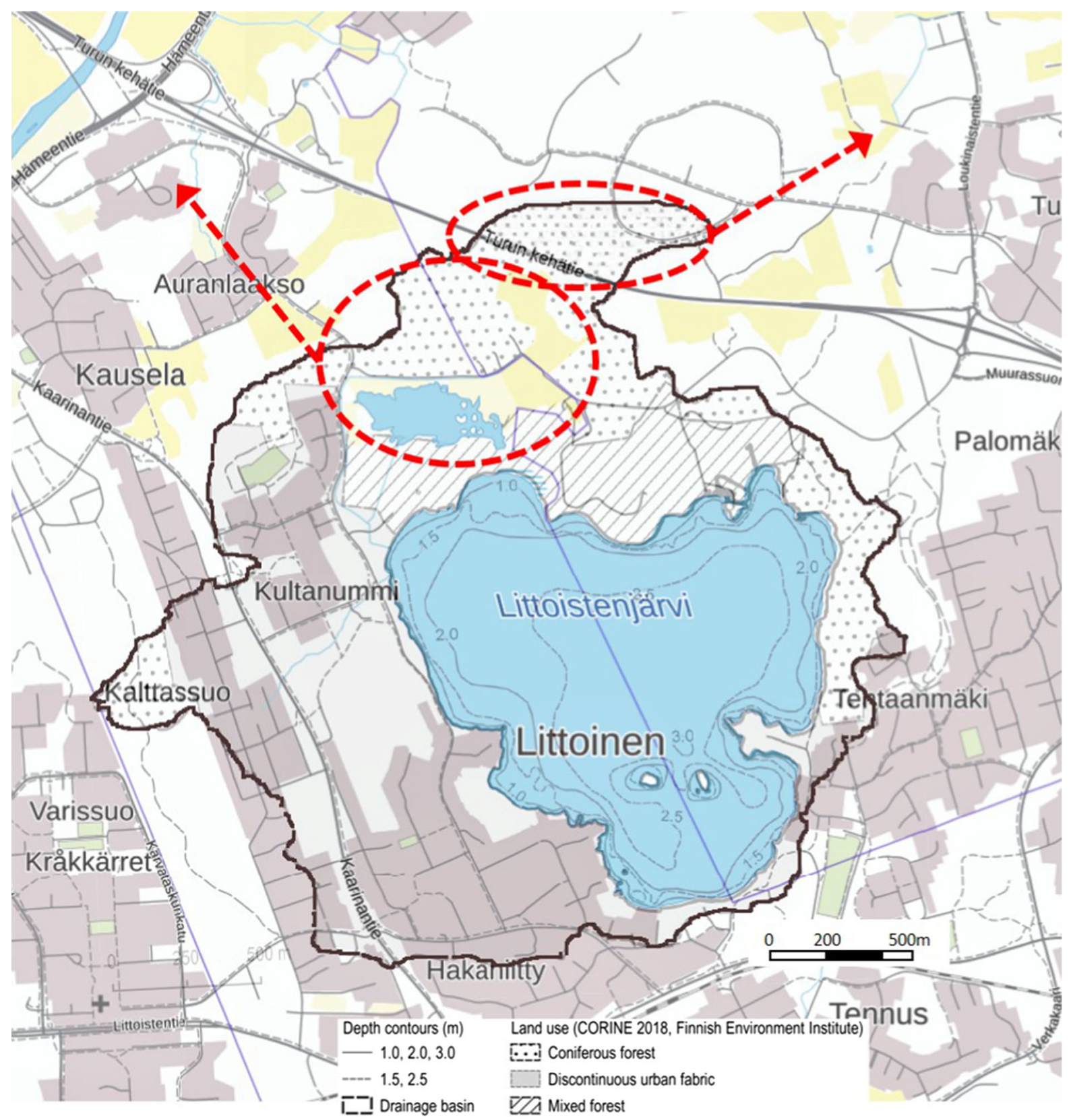

Fig. 1 Map of the lake Littoistenjärvi showing its bathymetry and catchment (background map from the open map service of the National Land Survey of Finland, complemented by the authors under CCBY4.0 licence; land uses from CORINE

because the terrain was mostly rocky, and loading from agricultural areas was rather restricted before the late 1940s, when the use of mineral fertilisers in Finland started to increase. The extent of arable fields was $7.5 \%$ of the total catchment in the 1960s-1980s. database of the Finnish Environment Institute; pale yellow = arable fields; blue area north of the lake = the wetland; broken line ellipses = approximate locations of the parts of the catchment from which runoff has recently been diverted)

Starting from 1971, the lake served as the raw water source for tap water production for the local municipalities, with strict protection against drainage area pollution. From the early 1980s to the end of water abstraction in late 1998, basically all inflowing water from the catchment was used to make tap water. In 


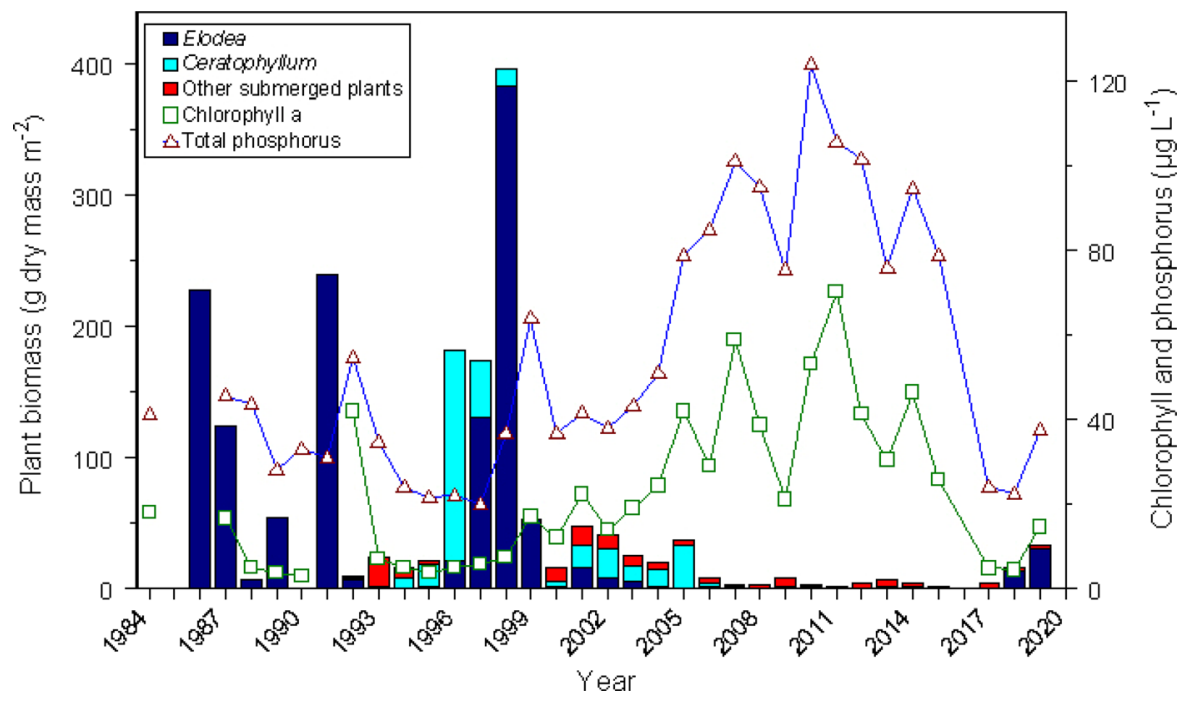

Fig. 2 Submerged plant biomass and average total phosphorus and chlorophyll $a$ concentrations in summer in Littoistenjärvi in 1986-2019

1983, Littoistenjärvi was still in about similar condition as in the beginning of the 1900s (Wahlberg, 1913; Rautanen et al., 1985). In the following two decades, however, the lake experienced rapid shifts between extreme clear-water and turbid states, associated with population cycles of the invasive submerged macrophytes Elodea canadensis Michx (later briefly Elodea) and Ceratophyllum demersum L. (later Ceratophyllum). Both species showed up in the 1960s, but their populations remained small until the mid-1980s when Elodea started to develop mass occurrences (Fig. 2). To be able to manage the problems caused to water abstraction, follow-up of macrophytes was started in 1986, and by 1992 it was expanded into comprehensive ecological monitoring. In the 2000s, the submerged macrophyte dominance was replaced by phytoplankton dominance and badly deteriorated water quality. To maintain or restore the usability of the lake, various management actions were taken over the years. As the lake is one of the few recreational lakes of the region, there was great interest to monitor and manage Littoistenjärvi water quality even after the water abstraction had ended.

\section{Methods used in following the lake ecosystem changes}

Submerged macrophytes

Starting from 1986, submerged plants were monitored once in late summer (Aug-Sep), or three times during the summer season (in 1996-1998), along ten littoral transects, perpendicular to the shoreline and evenly distributed around the lake, and ten stratified random sites in the central open area deeper than $1.5 \mathrm{~m}$. Plant cover and abundance were recorded by a diver from $2 \mathrm{~m}$ wide transects extending $50 \mathrm{~m}$ from the shoreline. The depth at the end of the transects was on average $1.5 \mathrm{~m}$ (range 0.9-2.1 m). In 1986 and 1987, the whole lake was divided in 10 strata, with 5 samples from each (in 1987 two). From 1988 onwards, plant biomass was assessed separately for the transect zone and the central area. Two quantitative biomass samples (three since 1996) were taken from each transect, and one from each of the central sites. Plants collected were washed, identified, dried at $60^{\circ} \mathrm{C}$, and weighed. Whole-lake values were calculated noting that the transect zone covered $20 \%$ of the total lake area.

In summers 1996-1998 when the biomass of Elodea was estimated three times during the summer, instantaneous growth rates were calculated for the littoral transect zone and the central open area from the equation 
$G\left(\right.$ day $\left.^{-1}\right)=\ln ($ final biomass/initial biomass $) /$ length of pefitoal $($ dán $9 \mathrm{~s})$ : Eq. 1, page 150). The annual minimum

Total phosphorus and nitrogen contents of Elodea were analysed from 41 samples representing different population densities in 1996-2018. Determinations were made by Southwest Finland Water and Environment Research with Finnish standard methods.

\section{Water quality}

Water quality sampling started as part of a national survey in 1963. Survey samples taken at three-year intervals were complemented with additional samples particularly in the 1980s. Since 1992, samples were collected with a Limnos sampler weekly or twice a month throughout each open-water season (from April-May to September-November, 10-15 dates annually), from 1 and $2 \mathrm{~m}$ depths at the deepest point of the lake, and analysed at Southwest Finland Water and Environment Research. In many years vertical profiles were also taken 1-3 times in winter from under the ice. Regular measurements included water temperature, $\mathrm{pH}$, Secchi depth transparency, total nitrogen (here later $\mathrm{TN}$ ), nitrate + nitrite and ammonium nitrogen, total phosphorus (here later TP) and soluble reactive phosphorus (SRP), and chlorophyll $a$ (Chl-a); in the ice-covered winter period also dissolved oxygen. In 1971-1998, the $\mathrm{pH}$ of intake water was measured every morning at 8:00 $\mathrm{h}$ by the staff of the water purification plant. Further parameters quantified at longer intervals were iron, manganese, aluminium, chloride, alkalinity, conductivity, turbidity and water colour. Occasional determinations of heavy metals and organic contaminants were also available (Sarvala \& Perttula, 1994). Analytical methods followed Finnish standard laboratory procedures accepted by the Finnish Accreditation Service FINAS. Water quality results are available in the Finnish Environment Institute's open data service.

Internal phosphorus loading

Summer months in the Littoistenjärvi area are usually quite dry so that the external loading in summer tends to be negligible. This made it possible to estimate internal phosphorus loading from the summer increase of TP concentrations in the same way as in another southwest Finnish lake, Säkylän Pyhäjärvi (Nürnberg concentrations were normally observed in spring after the ice-out, while the maximum concentrations were reached around mid-August. Accordingly, internal loading was calculated as the difference in average TP concentrations between May and August. Weather data for the nearest station in Yltöinen, $11 \mathrm{~km}$ away, were obtained from the open data service of the Meteorological Institute of Finland.

\section{Sediment chemistry}

Chemical characteristics of the bottom sediment were analysed from cores taken with the Limnos corer from the ice (March 2012, March 2015) or by a diver in open water (December 2018). The sediment was cut into 2-cm-thick slices down to $10 \mathrm{~cm}$, and into $5-\mathrm{cm}$ slices below $10 \mathrm{~cm}$. Subsamples of known volume were weighed, dried at $105{ }^{\circ} \mathrm{C}$, re-weighed, and loss on ignition was determined after incineration at $500^{\circ} \mathrm{C}$. Total phosphorus was determined according to Bengtsson (1979) with the molybdate method after wet combustion. Where appropriate, other subsamples were used for sequential fractionation of phosphorus. In 2012, phosphorus fractions were determined in the Geology Department of the University of Turku, following the methodology of Hieltes \& Lijklema (1980) (6 sites, 7 layers from 0 to $20 \mathrm{~cm}$ ). In 2015, TP, $\mathrm{Fe}$ and $\mathrm{S}$ contents were determined by Southwest Finland Water and Environment Research (6 sites, 0-6 cm), and in 2018, phosphorus fractions were determined in Swedish University of Agricultural Sciences in Uppsala with the methods of Hupfer et al. (1995) (6 sites, 8 layers from 0 to $30 \mathrm{~cm}$ ).

\section{Phytoplankton and zooplankton}

In 1983, phytoplankton and Chl- $a$ were sampled weekly or twice a week from April to October. Plankton samples were also available from JuneOctober 1987 and May-September 1988, and beginning from 1992, sampling covered the open-water season first at weekly, later fortnightly intervals (twice a week in 1992). Each sample consisted of two or three water columns taken with a Limnos tube sampler (6.8 or 3.5 l) from 0 to $2 \mathrm{~m}$ depth from different parts of the central open area. For phytoplankton, subsamples of $250 \mathrm{ml}$ were taken from each column, to be combined in the laboratory to one composite sample each date 
for microscopical counting. Chl- $a$ was determined from a 2-1 composite sample from 0 to $2 \mathrm{~m}$. Plankton samples were analysed in the University of Turku, and since 2000 by the same persons in Southwest Finland Water and Environment Research, with similar methods as in Sarvala et al. (1998). Phytoplankton was counted with an inverted microscope, applying the extensive quantitative counting procedure of the Finnish Environment Institute, consistent with the standard (CEN, 2006).

Zooplankton samples were taken at the same time with phytoplankton. Zooplankton samples comprised the whole volume of the composite sample columns, concentrated with a 25 or $50 \mu \mathrm{m}$ mesh net, and combined in the laboratory to form one composite sample each date. Using an inverted microscope, zooplankton subsamples were counted until 50-200 individuals of each dominant crustacean species had been measured. Their lengths were converted to carbon biomass using carbon to length regressions (as in Sarvala et al., 1998).

\section{Fish}

From 1993 onwards, the fish stocks in Littoistenjärvi were monitored with test fishing once a year using the Nordic gillnets (CEN, 2005: height $1.5 \mathrm{~m}$, length $30 \mathrm{~m}$, each net contains 12 mesh sizes from 5 to $55 \mathrm{~mm}$, knot to knot; 20 gillnet nights). Catch per unit effort (CPUE) was recorded as numbers and biomass of fish. In 1993-2012, fishing was done in early June, in 2015-2019 in late July-early September, and in 2013 and 2014, both in early and late summer to check for the effects of the shift in timing. Four sampling strata were used, and the gillnets were set for about $12 \mathrm{~h}$. Fishes were measured and weighed, and the results were recorded by mesh size, species and size group. Fish age was assessed from scales, otoliths, cleithra or opercula. In 1993-2016, growth was examined from size at age, while in 1995-1998 and 2017-2019, growth estimates were based on backcalculated lengths.

\section{Management actions in Littoistenjärvi: implementation and critical evaluation}

The invasive submerged macrophytes wholly dominated the ecosystem functioning in Littoistenjärvi in
1986-1999. Elodea biomass peaked in 1986, 1991 and 1997-1998, followed by population collapses in 1987, 1992 and 1999. Ceratophyllum was dominant in 1996 and moderately abundant from 1997 to 2005 . In 1987, most of the plants died during the winter because of anoxia, or freezing into the thick ice, while in 1992 the mass death was after the ice-out in May. In the winter 1999, the lake went almost completely anoxic under the ice, and most of the Elodea were killed (Fig. 2). Each collapse was followed by high nutrient and Chl$a$ levels during one summer, while clear-water conditions with low nutrient and Chl- $a$ levels prevailed in the following 2-4 years. After the third Elodea collapse, the submerged macrophytes did not recover, and the lake remained in the 2000s in a hypertrophic state dominated by cyanobacterial blooms. The successively worsening water quality problems elicited numerous management attempts in the catchment and in the lake, from aeration to removal of vegetation, reduction of external load, intensified fishing, and finally to chemical precipitation of phosphorus (Table 1). In the following sections, we critically assess the measures implemented and their success in combating specific environmental problems in the lake Littoistenjärvi.

Problem: the threat of winter anoxia

Elodea overwinters in an active state (Nichols \& Shaw, 1986), and its respiration causes oxygen deficit under the ice, when there is too little light for photosynthesis. In Littoistenjärvi, the late winter oxygen saturation close to the bottom was low, 20-40\%, even without Elodea in 1975-1981 (Sarvala \& Perttula, 1994). During its mass occurrences, Elodea was evenly distributed in the lake, including the open central part $>2 \mathrm{~m}$ deep, while in the intervening years it was restricted to shallower areas $(<1.5 \mathrm{~m})$. During the development of the first Elodea peak, the oxygen saturation in March 1986 went down to $5-23 \%$, but anoxia was avoided due to melting water inputs in late winter. Next winter, bottom waters went anoxic in March. The anoxia led to mass death of Elodea, and release of phosphorus and organic compounds from bottom sediment and plants into water. In the tap water production period, such development was not acceptable. 
Table 1 Management actions in Littoistenjärvi in 1987-2019

\begin{tabular}{|c|c|c|c|c|c|c|}
\hline $\begin{array}{l}\text { Management } \\
\text { problem }\end{array}$ & $\begin{array}{l}\text { Management } \\
\text { action }\end{array}$ & Management tool & Description & Performance & $\begin{array}{l}\text { Period of } \\
\text { operation }\end{array}$ & Notes \\
\hline \multirow[t]{7}{*}{$\begin{array}{l}\text { Threat of winter } \\
\text { anoxia }\end{array}$} & \multirow[t]{7}{*}{ Aeration } & $\begin{array}{l}\text { Planoks } 1 \text { surface } \\
\text { aerator }\end{array}$ & $\begin{array}{l}\text { An air pump installed } \\
\text { on a float }\end{array}$ & & $\begin{array}{r}\text { Mar 1987- } \\
\text { Dec } 1998\end{array}$ & $\begin{array}{l}\text { Planoks and } \\
\text { Listem 22,500 } \\
€ \text { (in 1987) }\end{array}$ \\
\hline & & $\begin{array}{l}\text { Listem subsurface } \\
\text { aerator }\end{array}$ & $\begin{array}{l}600 \mathrm{~m} \text { of tubing } \\
\text { installed above } \\
\text { bottom, compressed } \\
\text { air enters water as } \\
\text { microbubbles through } \\
800 \mathrm{slits} / \mathrm{m}\end{array}$ & $\begin{array}{l}20001 \mathrm{air} / \mathrm{min}, \text { or } \\
864 \mathrm{~kg} \mathrm{\textrm {O } _ { 2 }} / \mathrm{day}, \\
\text { dissolving efficiency } \\
25 \%\end{array}$ & $\begin{array}{l}\text { Oct 1987- } \\
\text { Dec 1998; } \\
\text { Feb 1999- } \\
\text { Mar 2002 }\end{array}$ & $\begin{array}{l}\text { Energy efficiency } \\
2.7-4.2 \mathrm{kgO}_{2} / \\
\mathrm{kWh} \text {. } \\
\text { Compressor } \\
\text { price 2,650€ } \\
\text { (in 1999) }\end{array}$ \\
\hline & & & & & & $\begin{array}{l}\text { Running costs } \\
\text { substantial }\end{array}$ \\
\hline & & $\begin{array}{l}\text { Water current } \\
\text { generator }\end{array}$ & $\begin{array}{l}\text { Underwater propeller } \\
\text { creates a water } \\
\text { current maintaining } \\
\text { the nearby area free } \\
\text { of ice, allowing } \\
\text { oxygen } \\
\text { replenishment of } \\
\text { water }\end{array}$ & $\begin{array}{l}\text { Kept at least a } 500 \mathrm{~m}^{2} \\
\text { area free of ice in } \mathrm{N} \\
\text { part of the lake; } \\
\text { another pump kept } \\
150 \mathrm{~m}^{2} \text { open in SE } \\
\text { part. Maintained the } \\
\text { whole lake minimally } \\
\text { oxygenated under ice }\end{array}$ & $\begin{array}{l}\text { Operated } \\
\text { during } \\
\text { winter } \\
\text { starting } \\
\text { from Dec } \\
2002\end{array}$ & $\begin{array}{l}\text { Originally used } \\
\text { to maintain an } \\
\text { open area for } \\
\text { winter } \\
\text { swimming }\end{array}$ \\
\hline & & Water pump & $\begin{array}{l}\text { Water was pumped to } \\
1 \mathrm{~m} \text { height above the } \\
\text { surface and expelled } \\
\text { to the air, } \\
\text { oxygenating while } \\
\text { falling down }\end{array}$ & $\begin{array}{l}100 \mathrm{~m}^{3} \text { water/hour. } \\
\text { Together with the } \\
\text { current generators } \\
\text { helped to maintain } \\
\text { the whole water } \\
\text { column oxygenated }\end{array}$ & $\begin{array}{l}\text { Jan-April } \\
2003\end{array}$ & $\begin{array}{l}\text { An ad hoc } \\
\text { solution to } \\
\text { prevent anoxia } \\
\text { of near-bottom } \\
\text { water during an } \\
\text { exceptionally } \\
\text { long ice-cover }\end{array}$ \\
\hline & & $\begin{array}{l}\text { Airit } 70 \text { surface } \\
\text { aerator }\end{array}$ & $\begin{array}{l}\text { A water pump installed } \\
\text { on a float }\end{array}$ & 691 water/s & $\begin{array}{l}\text { Oct 2011- } \\
\text { Mar } 2016\end{array}$ & $\begin{array}{l}1.5 \mathrm{~kW}, \\
\text { efficiency } \\
2.2 \mathrm{~kg} \mathrm{O}_{2} / \mathrm{kWh}\end{array}$ \\
\hline & & & & & & $\begin{array}{l}\text { Maintenance } \\
\text { service } 5000 € \\
\text { (2019) }\end{array}$ \\
\hline \multirow[t]{2}{*}{$\begin{array}{l}\text { Excessive } \\
\text { abundance of } \\
\text { submerged } \\
\text { macrophytes }\end{array}$} & \multirow[t]{2}{*}{$\begin{array}{r}\text { Removal of } \\
\text { vegetation }\end{array}$} & $\begin{array}{l}\text { Small-scale removal } \\
\text { of loose submerged } \\
\text { plants by } \\
\text { volunteers }\end{array}$ & $\begin{array}{l}\text { Floating macrophytes } \\
\text { were collected by } \\
\text { rakers on the shores } \\
\text { from where they were } \\
\text { transported to a } \\
\text { recycling centre for } \\
\text { composting }\end{array}$ & $\begin{array}{l}\text { Areas in front of } \\
\text { swimming beaches } \\
\text { were kept more or } \\
\text { less open. In 1992, } \\
\text { some } 500 \text { tons of } \\
\text { Elodea ( } 3 \text { tons/ha) } \\
\text { removed }\end{array}$ & $\begin{array}{l}\text { May-June } \\
1992, \text { Sep } \\
2018, \\
\text { May-Sep } \\
2019\end{array}$ & $\begin{array}{l}\text { Costs of plant } \\
\text { removal: } \\
\text { In 1992: } 13,500 € \\
\text { 1996: } 2,500 € \\
\text { 1997: } 21,000 €\end{array}$ \\
\hline & & $\begin{array}{l}\text { Large-scale } \\
\text { mechanical plant } \\
\text { removal using } \\
\text { Aquatic Weed } \\
\text { Harvester RS2000 }\end{array}$ & $\begin{array}{l}\text { A paddle-wheel boat } \\
\text { with front cutters and } \\
\text { a conveyer belt to } \\
\text { collect the loosened } \\
\text { plants for transport to } \\
\text { the shore. Capacity } \\
\text { up to } 1 \text { hectare per } \\
\text { hour }\end{array}$ & $\begin{array}{l}\text { Cutting depth } \\
\text { adjustable down to } \\
2 \text { m. Shallow } \\
\text { minimum draught } \\
(0.65 \mathrm{~m}) \text { allows } \\
\text { working close to the } \\
\text { shore, and direct } \\
\text { landing of collected } \\
\text { plants. Up to } 700 \text { tons } \\
\text { of Elodea }(5 \text { tons } / \mathrm{ha}) \\
\text { removed in } 1998\end{array}$ & $\begin{array}{l}\text { Summers } \\
1996-1998\end{array}$ & $\begin{array}{l}45 € / \text { ton of plants } \\
\text { Estimated total } \\
\text { cost for } 1998 \\
\text { thus } \\
31,500 €\end{array}$ \\
\hline
\end{tabular}


Table 1 continued

\begin{tabular}{|c|c|c|c|c|c|c|}
\hline $\begin{array}{l}\text { Management } \\
\text { problem }\end{array}$ & $\begin{array}{l}\text { Management } \\
\text { action }\end{array}$ & Management tool & Description & Performance & $\begin{array}{l}\text { Period of } \\
\text { operation }\end{array}$ & Notes \\
\hline \multirow[t]{3}{*}{$\begin{array}{l}\text { Intense } \\
\text { cyanobacterial } \\
\text { blooms }\end{array}$} & $\begin{array}{l}\text { Reduction of } \\
\text { external } \\
\text { loading }\end{array}$ & $\begin{array}{l}\text { Development of } \\
\text { municipal sewage } \\
\text { system } \\
\text { Construction of } \\
\text { settling basins to } \\
\text { stormwater sewers } \\
\text { Creation of a wetland } \\
\text { Diversion of parts of } \\
\text { catchment }\end{array}$ & & $\begin{array}{l}\text { All houses except } 5 \\
\text { connected to the } \\
\text { municipal sewage } \\
\text { system } \\
\text { Runoff diverted from } \\
40 \% \text { of catchment } \\
\text { area }\end{array}$ & $\begin{array}{l}\text { Sewage } \\
\text { system } \\
1980 \text { s- } \\
2010 \text { s } \\
\text { Wetland } \\
\text { created } \\
2009 \\
\text { Runoff from } \\
\text { wetland } \\
\text { diverted } \\
2011 \\
\text { Diversion of } \\
\text { industrial } \\
\text { area } 2019\end{array}$ & $\begin{array}{l}\text { External loading } \\
\text { reduced } \\
\text { possibly by } \\
58 \% \text { from the } \\
\text { early 1990s to } \\
2020\end{array}$ \\
\hline & $\begin{array}{l}\text { Food-web } \\
\text { manipulation } \\
\text { by fishing }\end{array}$ & $\begin{array}{l}\text { Pound nets } \\
\text { Seine netting } \\
\text { Bream gillnets }\end{array}$ & $\begin{array}{l}\text { Pound nets were set for } \\
\text { the spring period } \\
\text { Apr-June. Winter } \\
\text { seining was } \\
\text { attempted when ice } \\
\text { conditions allowed, } \\
\text { fishable flocks were } \\
\text { located by sonar }\end{array}$ & $\begin{array}{l}\text { Pound net catches } \\
1-42 \mathrm{~kg} / \mathrm{ha} / \mathrm{a} \text { (mainly } \\
\text { roach), winter seine } \\
\text { catch } 16 \mathrm{~kg} / \mathrm{ha} \\
\text { (mainly bream) }\end{array}$ & $\begin{array}{l}\text { 2006-2015 } \\
\text { (pound } \\
\text { nets); Feb } \\
2009 \\
\text { (winter } \\
\text { seine } \\
\text { netting) }\end{array}$ & $\begin{array}{l}\text { Total annual } \\
\text { costs of fishing } \\
\text { about } 10,000 €\end{array}$ \\
\hline & $\begin{array}{l}\text { Reduction of } \\
\text { internal } \\
\text { loading by } \\
\text { chemical } \\
\text { precipitation } \\
\text { of } \\
\text { phosphorus }\end{array}$ & $\begin{array}{l}\text { Polyaluminium } \\
\text { chloride PAX } \\
\text { XL100 of Kemira } \\
\text { Oyj, applied in } \\
\text { water with the } \\
\text { special boats of the } \\
\text { company } \\
\text { Ympäristö- } \\
\text { Ojansuut Oy }\end{array}$ & $\begin{array}{l}\text { The liquid chemical } \\
\text { was distributed by } \\
\text { driving across the } \\
\text { lake along parallel } \\
\text { transects. A smaller } \\
\text { boat was used for } \\
\text { shallow water. The } \\
\text { boats have on both } \\
\text { sides 5-m pipes with } \\
\text { openings at regular } \\
\text { intervals through } \\
\text { which the liquid is } \\
\text { dripping into water }\end{array}$ & $\begin{array}{l}\text { The whole lake area, } \\
150 \mathrm{ha} \text {, was covered } \\
\text { in } 36 \mathrm{~h} \\
\text { Water clarified in } 24 \mathrm{~h}\end{array}$ & $\begin{array}{l}\text { 11-12 May } \\
2017\end{array}$ & $\begin{array}{l}\text { Costs: } \\
\text { Environmental } \\
\text { permit } 4,000 € \\
\text { Treatment alone } \\
\text { 1,000€/ha. } \\
\text { Extensive } \\
\text { monitoring } \\
\text { 500€/ha }\end{array}$ \\
\hline
\end{tabular}

\section{Management action 1: aeration}

The management action taken was wintertime aeration, started in March 1987 with one aerator (Table 1). Another aerator was added in autumn 1987, and both were run until December 1998 when the municipal water abstraction ended, and both aerators broke down. One of these could be run intermittently later that winter, and in the following winters it was run until the final break-down in 2002. After this, aeration was accomplished with simple current generators maintaining two small ice-free areas. In the harsh winter 2002-2003, an additional pump was discharging water in the air, to fall down from $1 \mathrm{~m}$ height. Two new aerators were installed in 2012, and run until 2016.
Under-ice water quality samples revealed that aeration effectively kept the oxygen saturation $>60 \%$. The vertical oxygen profiles were similar all over the lake even if the aerators were located close to the shores (in six winters the maximum difference in close-to-bottom saturation between three sites was 5-12\%). In 1987, when the bottom water went anoxic in March for the first time, the first aerator then installed could still oxygenate the whole water volume in one month before the ice-out. In 1988-1998, even though submerged macrophytes were abundant, two aerators could prevent anoxic conditions in bottom water. In winter 1999, when only one aerator was functioning for part of the winter, almost complete anoxia developed, and the Elodea population collapsed. After 1999, macrophytes remained scarce, 
enabling the current generators and ad hoc aeration to prevent anoxia even under the long ice-cover in 2002-2003. In 2012-2015, when macrophytes were also scarce, aeration likewise prevented anoxia, and reduced the summertime TP and Chl- $a$ contents by $20 \%$ compared to the preceding three years without aerators.

Overall, aeration was efficient in keeping the whole water column oxygenated, and preventing wintertime release of phosphorus from the sediment. But as observed in 2012-2015, the reductions in nutrient levels were not sufficient to improve the hypertrophic state of the lake. Moreover, oxygenated conditions under the ice favoured the overwintering of Elodea, and may have accelerated the development of excessive macrophyte biomass. In practice, however, dense but living stands of submerged macrophytes may be a better alternative compared to plants dying because of anoxia—as seen in Littoistenjärvi in the 1980s and 1990s, live macrophytes kept the nutrient levels in water low. But aeration was not able to prevent the deterioration of water quality in the 2000s. In the same vein, other recent studies have concluded that although aeration improves the oxygenation of water, it has little influence on the nutrient levels in the whole water mass (e.g. Salmi et al., 2014; Bormans et al., 2016; Kuha et al., 2016; Visser et al., 2016). Thus, it is unlikely that aeration alone could restore the water quality in Littoistenjärvi or elsewhere.

Problem: excessive abundance of submerged macrophytes

During their peak biomass in 1986, 1991 and 1996-1998, submerged macrophytes started to hinder recreational use of the lake. Swimming and rowing became difficult, because plant shoots extended from bottom to surface throughout the lake. Local anoxia was also likely to develop in summer nights under the dense macrophyte stands, leading to leakage of phosphorus into water. Occasional pulses of SRP were indeed observed in summer 1998 when macrophyte density was at its highest. A third problem arising from the dense Elodea stands was that ironand aluminium-bound phosphorus can potentially be released when sediment $\mathrm{pH}$ rises over 8.5 (Niemistö et al., 2011). Moreover, in connection with the population crashes, the dying Elodea released large amounts of nutrients, resulting in dense algal blooms and turbid water for one summer. During its peak biomass periods, Elodea completely dominated the nutrient balance of the whole ecosystem. The phosphorus content of living Elodea in June-September 1996-2001 was $0.61 \pm 0.06 \%$ of dry mass (mean \pm SE). Dense and sparse populations did not differ, but TP content was highest in July. From the mean TP content, the phosphorus accumulated in Elodea biomass in the peak years was $2200 \mathrm{~kg}$ P in the whole lake, i.e. 22-fold compared to storage in water (97 kg), and 27 -fold the external load of that time $\left(82 \mathrm{~kg} \mathrm{a}^{-1}\right)$; only the sediment storage was larger. In the low population phase 2000-2015, TP in Elodea was <3\% of the storage in water.

\section{Management action 2: removal of vegetation}

As a remedy, removal of excessive vegetation was tried. At first, floating plants were collected by voluntary citizens on the shores for transport to a compost dump. In 1996-1998, a special machinery, Aquatic Weed Harvester RS 2000, originally designed for removal of Ceratophyllum, was used. Simpler cutting equipment was tried but found unsuitable.

In 1992, 510 tons of living and dead, partly decomposed vegetation, mainly Elodea, were removed from the lake. This was approximately half of the total biomass in the previous autumn. In 1996-1998, 306-700 tons of submerged macrophytes were removed annually. Even when 700 tons, or twice the average biomass that summer, were removed in 1998, Elodea biomass did not decline.

Attempts to reduce Elodea by mechanical collection can thus be regarded as a failure. This was because of the strong density dependence of the growth of the plant. Even the most intensive macrophyte removal in 1996-1998 did not appreciably reduce the total biomass of Elodea. Instead, biomass removal led to greatly elevated growth rates of the remaining plants (Fig. 3), compensating for the removals during the same summer. Accordingly, photosynthesis of Elodea resulted in very high maximum $\mathrm{pH}$ values, up to $>10$. Yet there were no signs of phosphorus release from the sediment. This might be because $\mathrm{pH}$ remains lower in the sediment than in water; our data from 1987 and 1988 suggest a difference of $1.5-2 \mathrm{pH}$ units, in line with the findings of Huser et al. (2016a). As a conclusion, removal of vegetation was considered futile and was discontinued. In restricted areas off 
Fig. 3 Instantaneous growth rate of Elodea relative to the initial biomass in Littoistenjärvi

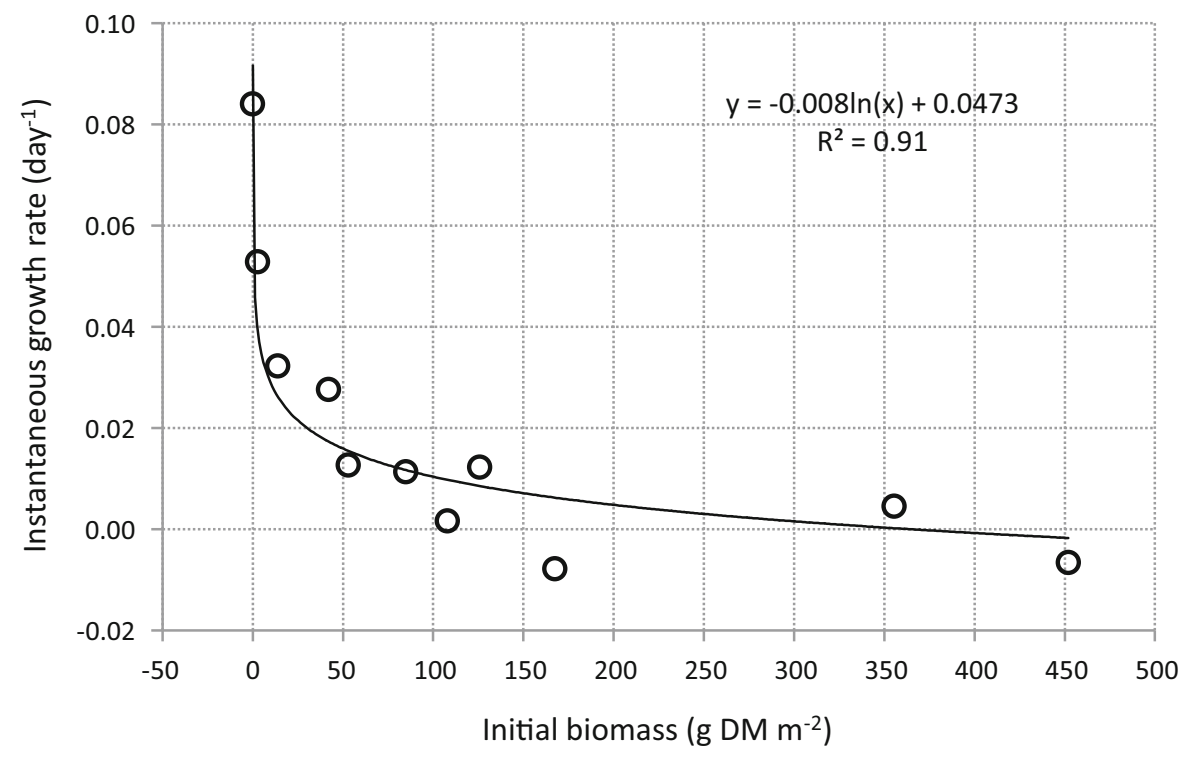

swimming beaches and boat piers, plant harvesting could be worthwhile.

Problem: Intense cyanobacterial blooms

In the beginning of the study period, in 1978-1981, the total nutrient levels of Littoistenjärvi indicated eutrophy (TP in May-September $\sim 50 \mu \mathrm{g} \mathrm{l}^{-1}$; Fig. 4), but water quality was rather good, with Chl$a$ levels $<5 \mu \mathrm{g} \mathrm{l}^{-1}$, and transparency $>2.5 \mathrm{~m}$ (Rautanen et al., 1985). In the submerged macrophytedominated period 1986-1998, the ecosystem showed rapid fluctuations between extreme clear-water and turbid states. In the clear years, TP, TN and Chl$a$ concentrations were low and transparency high (often down to the bottom), and the TP level gradually declined to about $20 \mu \mathrm{g} \mathrm{P}{ }^{-1}$ in the mid-1990s. In Elodea's collapse years, nutrient and Chl- $a$ concentrations were high and transparency low, but cyanobacteria were blooming only in May-June 1992. Judging from high values of the daily $\mathrm{pH}$ records, short 2-3week cyanobacterial blooms had earlier occurred in 1976, 1980 and 1984, and similar blooms of partly the same species (e.g. Anabaena lemmermannii P. Richter) were reported from Littoistenjärvi already in 1908-1912 (Wahlberg, 1913).

In 1978-2018, phytoplankton Chl- $a$ levels were predictable from TP (Fig. 4). Also the total phytoplankton and cyanobacterial biomasses were related to $\mathrm{TP}$, although to a lesser extent. The share of cyanobacteria of the total phytoplankton biomass was much less determined by the phosphorus level, so that cyanobacteria were often dominant even at rather low TP level.

A closer look at the seasonal dynamics revealed that often TP rose first (e.g. due to anoxia or high $\mathrm{pH}$ ), and TN followed later, most likely as a result of nitrogen fixation by blooming cyanobacteria. Consistent with this, TN and TP concentrations showed high correlation (Fig. 4). In summer, the SRP concentrations were almost always below the detection limit. Of the inorganic nitrogen forms, the $\mathrm{NO}_{3}-\mathrm{NO}_{2}-\mathrm{N}$ was mostly below the detection limit, with detectable concentrations in late autumn in some years, but some free $\mathrm{NH}_{4}-\mathrm{N}$ was often observed towards the autumn, occasionally at any time of the summer. These patterns suggest that the plankton system in Littoistenjärvi was P-limited or co-limited by $\mathrm{P}$ and $\mathrm{N}$.

In spite of the intervening single turbid-water years, water quality during the Elodea dominance in the 1980 s and 1990s and a few years afterwards was mostly acceptable for recreational activities, and the tap water production could be continued by adding activated carbon to the purification process to remove possible cyanobacterial toxins.

In the 2000s, after the decline of Elodea in 1999, however, a major change happened. Intense cyanobacterial blooms lasting for up to 5-6 months every summer started in 2000, and a little later, in 2003-2006, TP and TN concentration phased to new 

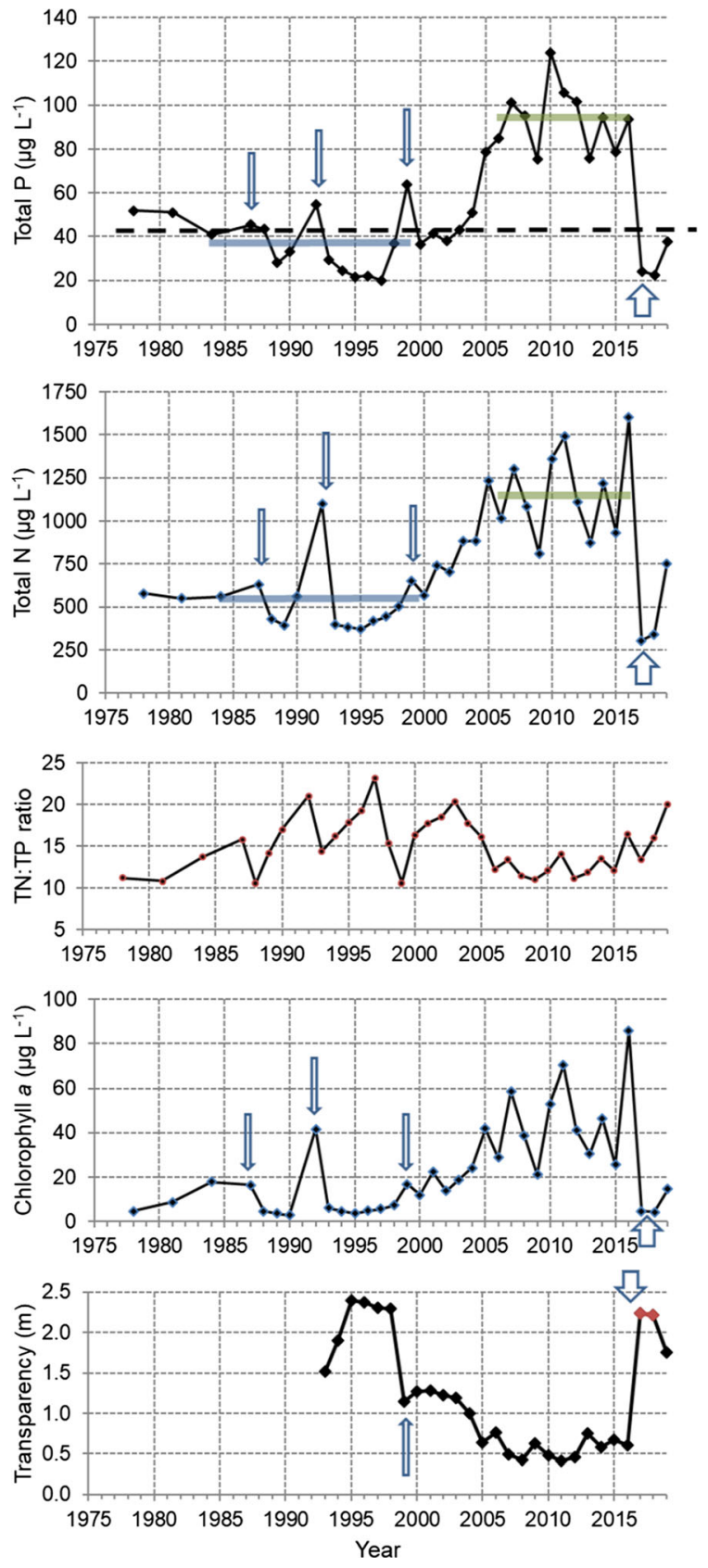

highs of $80-120 \mu \mathrm{g} \mathrm{P}^{-1}$, and $800-1500 \mu \mathrm{g} \mathrm{N} 1^{-1}$, around which they started to fluctuate (Fig. 4). Low values of the TN:TP mass ratio prevailed in 2006-2016, indicating that the nutrient environment in these years favoured nitrogen-fixing cyanobacteria.

After 2005, the stinking summer blooms of cyanobacteria rendered Littoistenjärvi practically unusable for human purposes, and the local citizens demanded urgent management actions. Because the
4Fig. 4 From top to bottom: Average total phosphorus, total nitrogen, mass ratio of total nitrogen and total phosphorus, chlorophyll $a$ concentration, and Secchi disk transparency in Littoistenjärvi in summer (1 May-15 September) in 1978-2019 (1 July-15 September in 2017) (broken line in the uppermost panel $=$ total phosphorus concentration expected from external loading and water residence time (Ahlgren et al., 1988); horizontal bars $=$ average total phosphorus and nitrogen values for the submerged macrophyte-dominated period 1984-1999, as well as for the phytoplankton-dominated turbid period 2006-2016; narrow vertical arrows =Elodea collapse years 1987, 1992 and 1999; thick block arrow = the chemical treatment year 2017)

water quality and usability of Littoistenjärvi were ultimately dependent on the availability of phosphorus in lake water, the management actions focused on the amount and fate of phosphorus in the system, aiming at reducing the external and internal loads.

\section{Management action 3: reduction of external phosphorus loading}

Reduction of external loads is the primary approach in combating eutrophication (Jeppesen et al., 2012; Hamilton et al., 2016). Although the nutrient loading to Littoistenjärvi never much exceeded the background diffuse loading, its further reduction was the goal of environmental authorities. Along with the development of the municipal sewage system, the number of houses not belonging to the system and relying only on septic tanks was reduced. Settling basins were constructed in stormwater sewers draining into the lake. Cultivation of the few arable fields was discontinued, and the last field was transformed into a wetland for waterfowl in 2009. Two years later, wetland waters were diverted away from the lake. In addition, runoff from a new industrial area in the northernmost corner of the catchment is currently (2019) being diverted (Fig. 1).

Based on field measurements of inflows, the external phosphorus loading into Littoistenjärvi in 1992-1993 was estimated at $138 \mathrm{~kg} \mathrm{P} \mathrm{a}^{-1}$ or $0.092 \mathrm{~g} \mathrm{P}$ $\mathrm{m}^{-2} \mathrm{a}^{-1}$ (Sarvala \& Perttula, 1994). The most important phosphorus source was the arable fields, and other significant components were forested areas, rural houses and aerial deposition. During 1980-2010, the municipal wastewater system, which drains the treated sewage directly into the Baltic Sea, was extended to the whole catchment, and all houses except five had joined the system by the year 2020 . 


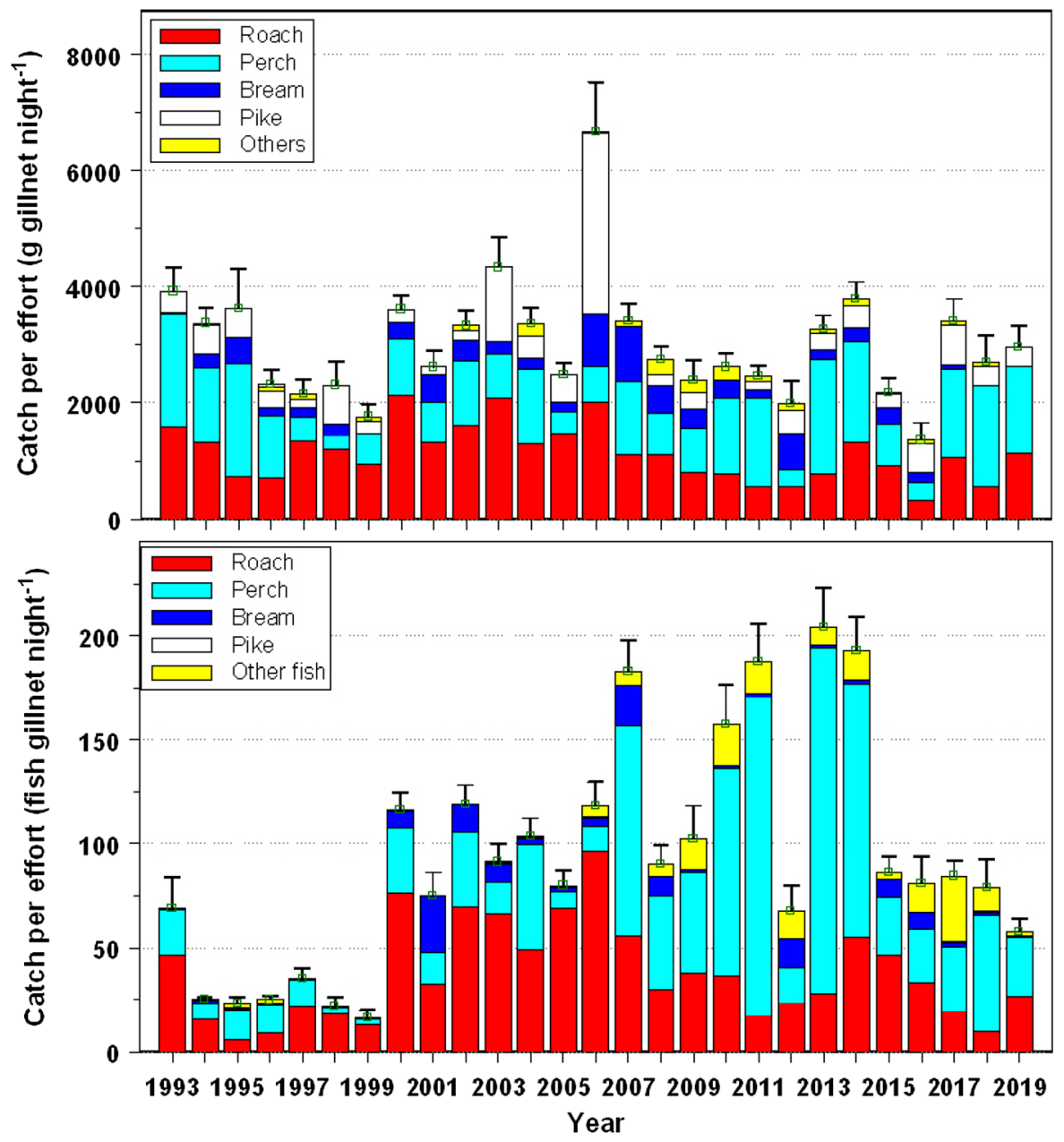

Fig. 5 Biomass (top) and numbers (bottom) of fish caught per gillnet night in test fishings of Littoistenjärvi in 1993-2018

According to the process-based model VEMALA, developed for quantifying nutrient inputs and losses in Finnish lakes (Huttunen et al., 2016), the external load of total phosphorus to Littoistenjärvi in 2001-2010 was $82 \mathrm{~kg} \mathrm{P} \mathrm{a}^{-1}$ or $0.054 \mathrm{~g} \mathrm{P} \mathrm{m}^{-2} \mathrm{a}^{-1}$ (Markus Huttunen, Finnish Environment Institute, Helsinki, personal communication). The diversion of the highphosphorus waters (up to $290 \mu \mathrm{g} \mathrm{P}^{-1}$ ) from the wetland reduced the total external load by at least onethird to $55 \mathrm{~kg} \mathrm{P} \mathrm{a}^{-1}$ or $0.036 \mathrm{~g} \mathrm{P} \mathrm{m}^{-2} \mathrm{a}^{-1}$, and the ongoing diversion will lead to further reductions.

The Littoistenjärvi catchment is small, and therefore external loading was not considered to be a major driver of the ongoing environmental problems in the lake. The gradually widened coverage of the wastewater system removed most of the point load from the human settlements in spite of the considerable increase in the number of houses and inhabitants. A major reduction of external load also followed from the diversion of the high-phosphorus waters of the present wetland. In all, the diverted area was close to $40 \%$ of the catchment (Fig. 1). The construction of settling basins in the stormwater systems is not expected to have had a significant impact on the external loading due to their small size. The existing estimates suggest that overall, the external phosphorus load decreased by $58 \%$ during the last three decades. Part of this change is real, although part is due to improved estimates. This is about as big reduction as was possible, but still the lake remained hypertrophic after the completion of these measures. 


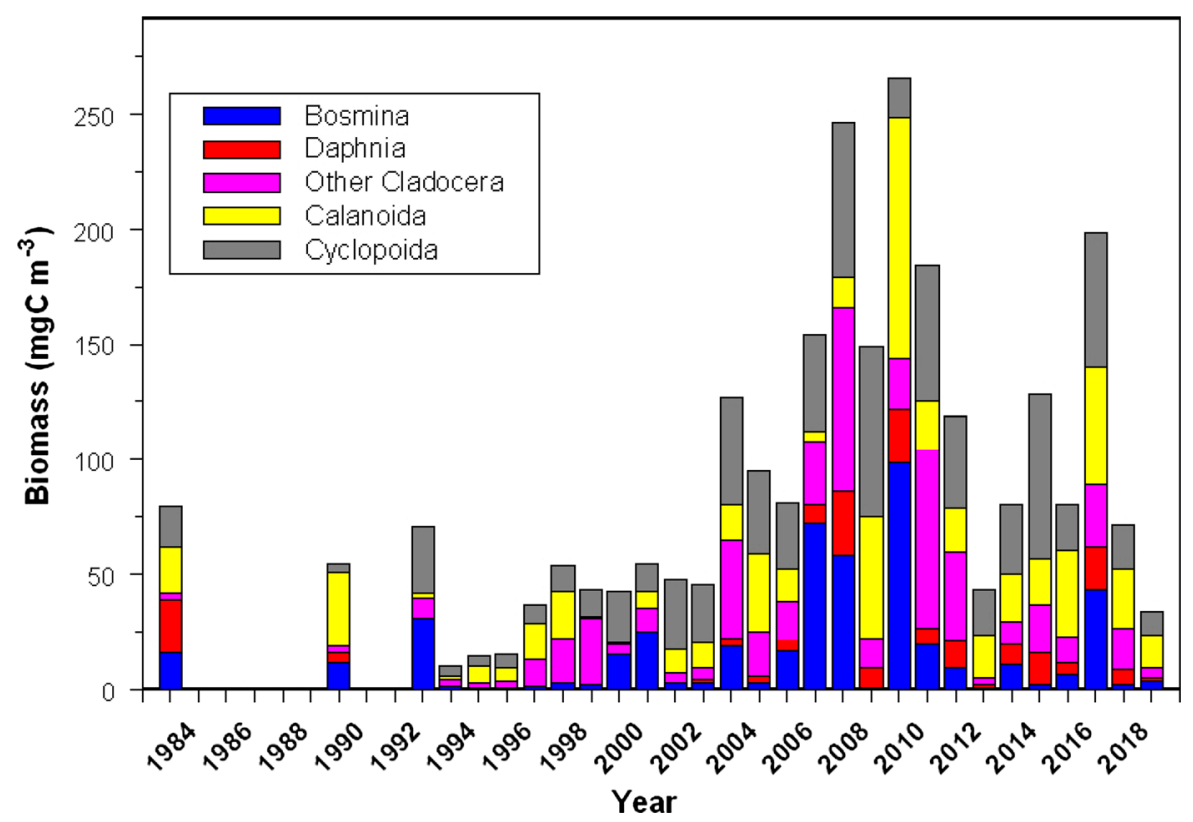

Fig. 6 Average biomass of crustacean zooplankton in Littoistenjärvi in summer (1 May-15 September) in 1983-2018

\section{Management action 4: food-web manipulation by fishing}

Reduction of planktivorous and benthivorous fish can reduce the prevalence of cyanobacterial blooms by replacing small-sized zooplankton with larger and more efficient herbivores and by reducing leakage of phosphorus from the sediment (Jeppesen et al., 2012). Test fishings with the Nordic gillnets in 1993-2018 indicated that both planktivorous and benthivorous fish were very abundant in Littoistenjärvi (Fig. 5), suggesting that there was potential for food-web manipulation. Roach (Rutilus rutilus [Linnaeus]), perch (Perca fluviatilis Linnaeus), bream (Abramis brama [Linnaeus]) and pike (Esox lucius Linnaeus) were the main species. Temporal changes in the biomass CPUE were small relative to the normal variability of the catches. In contrast, the CPUE in numbers suddenly increased fivefold in 2000 to $>100$ fish gillnet night ${ }^{-1}$, decreasing in 2015-2019 to $<60$ fish gillnet night ${ }^{-1}$. This reflected a major change in the fish assemblage structure. In the 1990s, big perch and roach were common, but in the 2000s and 2010s, none of the perch or roach have grown big. Similarly, in the 1990s, a few big bream and no small ones were caught, but the 1999 year-class was strong, and could be followed in the catches up to 2006, when its

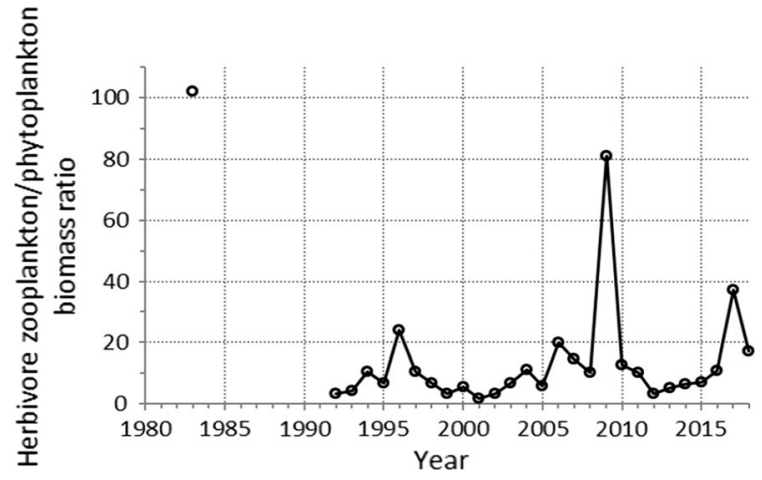

Fig. 7 Biomass ratio of herbivorous crustacean zooplankton to phytoplankton ( $\mathrm{g}$ wet mass $\mathrm{m}^{-3} / \mathrm{g}$ wet mass $\mathrm{m}^{-3}$ ) in Littoistenjärvi in May-September in 1983 and 1992-2018

offspring appeared in catch as a pulse of small bream; the offspring of the latter appeared in 2014. Consistent with fish abundance, crustacean zooplankton was in most years dominated by small-sized cladocerans and cyclopoids, indicating high predation pressure by fish (Fig. 6). Consequently, zooplankton to phytoplankton mass ratios high enough to enable grazing control of phytoplankton only appeared in two years when Daphnia galeata G. O. Sars 1864 was abundant (1983, 2009; Fig. 7). Reduction of the planktivorous fish populations could thus enhance the grazing control of phytoplankton in Littoistenjärvi, and 
simultaneous reduction of benthivorous fish might decrease the release of phosphorus from the bottom.

In 2006-2015, attempts were made to reduce the cyprinid fish. In eight years, 3-4 pound nets were set after the ice-out for 3-6 weeks in 3-4 places. Big predatory fish (pike and perch) were released. Big bream and crucian carp (Carassius carassius [Linnaeus, 1758]) were caught in 2008 with 20 special gillnets constructed for fishing bream (65 and $75 \mathrm{~mm}$ knot to knot). Seine netting in open water in autumn was tried in September 2009, but catchable aggregations of fish were not found, and fishing was discontinued because catches remained small. Weak ice conditions and restricted availability of fishing crews hindered winter seining except in 1 year (2009).

The reduction of planktivorous fish as a management method to prevent cyanobacterial blooms has been successful only when fish catches have been high enough (Hansson et al., 1998; Jeppesen \& Sammalkorpi, 2002; Søndergaard et al., 2007; Jeppesen et al., 2012), up to 70-85\% of fish biomass (Perrow et al., 1997; Hansson et al., 1998; Meijer et al., 1999; Sarvala et al., 2000b). Target catches also increase with increasing nutrient levels, because the production of fish then increases (Jeppesen \& Sammalkorpi, 2002). Effects of fishing have also been temporary. There have been several cases in which a complete fish kill made water clear, but the fish community recovered and water quality returned to previous level in about 3 years (Sarvala et al., 2000a; Ruuhijärvi et al., 2010). The presence of invertebrate predators may also complicate the food-web relationships (LiljendahlNurminen et al., 2003).

In Littoistenjärvi, catches from spring-time pound net fishing in 2006-2015 varied from 1 to $42 \mathrm{~kg} \mathrm{ha}^{-1}$ $\mathrm{a}^{-1}$, mainly roach. In winter $2009,16 \mathrm{~kg} \mathrm{ha}^{-1}$ of mainly bream were caught with a seine net. The overall catches were $188 \mathrm{~kg} \mathrm{ha}^{-1}$, but when this was divided to nine years, the average annual catch was only $21 \mathrm{~kg} \mathrm{ha}^{-1}$ or so low that no water quality improvements could be expected (Jeppesen \& Sammalkorpi, 2002).

\section{Management action 5: reduction of internal loading by chemical precipitation of phosphorus}

In spite of the previous management efforts, the lake remained in hypertrophic condition in 2006-2016. In the latest official EU Water Framework Directive

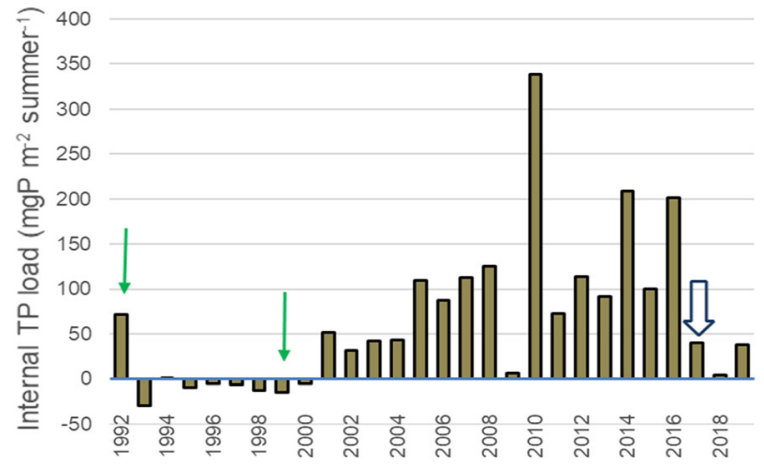

Fig. 8 Internal loading of total $\mathrm{P}$ in Littoistenjärvi in 1992-2019, calculated from the difference in average TP concentrations between May and August (thin vertical arrows = Elodea collapse years, thick open arrow $=$ the year of chemical precipitation of phosphorus)

evaluation (2013) based on monitoring data from 2006 to 2012, the ecological state of the lake was judged poor, and it seemed to be getting still worse. A further cause of concern was that the cyanobacterial blooms (particularly Anabaena spp, in some years also Microcystis spp) turned out to be toxic (high concentrations of microcystins were determined; unpublished report by M. Vehniäinen, University of Turku). In this state, Littoistenjärvi was almost unusable, and there was growing willingness among the local inhabitants to use stronger interventions, among them chemical treatment, to restore the lake.

The main problem after the end of Elodea dominance in the 2000s was internal loading, i.e. release of phosphorus from bottom sediment, which increased TP of water three- or fourfold during the summer. In the macrophyte-dominated period, internal loading was negative, but after the decline of Elodea, it started to increase in 2001, and rose to about $100 \mathrm{mg} \mathrm{P} \mathrm{m}^{-2}$ summer $^{-1}$ by 2005 (Fig. 8). Although these estimates may in some years include some external loading, they did not show any correlation with June-August rainfall, suggesting a minor confounding effect of external load. Moreover, the average external load in May-August would be so low (14 $\mathrm{mg} \mathrm{P} \mathrm{m}^{-2}$ or $9 \mathrm{mg} \mathrm{P}$ $\mathrm{m}^{-2}$ after 2011) as to have minimal influence on the overall pattern. In the period 2005-2016, internal loading showed a significant correlation with maximum summer temperature and maximum $\mathrm{pH}$. In 2005-2016, the average internal TP loading in summer $\left(131 \pm 24 \mathrm{mg} \mathrm{P} \mathrm{m}^{-2}\right.$; mean $\left.\pm \mathrm{SE}\right)$ exceeded the annual external load roughly threefold, and was the 
Table 2 Phosphorus fractions obtained with sequential extraction in the $0-10 \mathrm{~cm}$ layer of Littoistenjärvi sediment before (2012) and after (2018) precipitation of phosphorus with aluminium (mean \pm standard error; $N=30$ )

\begin{tabular}{|c|c|c|c|c|c|}
\hline & $\begin{array}{l}2012 \\
\mathrm{mg} \mathrm{P}^{-1} \text { dry mass }\end{array}$ & $\begin{array}{l}2018 \\
\mathrm{mg} \mathrm{P} \mathrm{g}^{-1} \text { dry mass }\end{array}$ & Ratio $2018 / 2012$ & $\mathrm{P}$ & $\begin{array}{l}2012 \\
\mathrm{mg} \mathrm{P} \mathrm{cm}^{-3}\end{array}$ \\
\hline Total phosphorus & $2.12 \pm 0.10$ & $2.23 \pm 0.04$ & 1.05 & 0.16 & $0.166 \pm 0.008$ \\
\hline $\mathrm{NH}_{4} \mathrm{Cl}-\mathrm{P}$ & $0.03 \pm 0.004$ & $0.01 \pm 0.001$ & 0.38 & $<0.001$ & $0.002 \pm 0.0002$ \\
\hline $\mathrm{NaOH}-\mathrm{P}$ & $0.50 \pm 0.05$ & $0.98 \pm 0.03$ & 1.97 & $<0.001$ & $0.038 \pm 0.004$ \\
\hline HCl-P & $0.33 \pm 0.05$ & $0.16 \pm 0.01$ & 0.48 & $<0.002$ & $0.026 \pm 0.005$ \\
\hline Residual P & $1.26 \pm 0.10$ & $0.80 \pm 0.02$ & 0.63 & $<0.001$ & $0.100 \pm 0.007$ \\
\hline Fe-bound $\mathrm{P}$ (BD extraction) & & $0.33 \pm 0.02$ & & & \\
\hline Al-bound P & & $0.65 \pm 0.02$ & & & \\
\hline
\end{tabular}

In 2018, the first step, $\mathrm{NH}_{4} \mathrm{Cl}$ extraction, was followed by a Na-bicarbonate and Na-dithionite-extraction step (BD extraction) delivering redox-sensitive $\mathrm{P}$ mainly bound to Fe hydroxides (Hupfer et al., 1995). The $\mathrm{NaOH}$ extraction that followed then yielded $\mathrm{P}$ regarded as mainly Al-bound. The $\mathrm{NaOH}-\mathrm{P}$ value given for 2018 is the sum of these two fractions, approximately corresponding to the $\mathrm{NaOH}-\mathrm{P}$ in 2012 when the BD extraction was omitted. Statistical significance of the 2018 versus 2012 comparison indicated (t test, unequal variances). The last column gives the 2012 values calculated per sediment volume

main factor leading to the increased TP level in the 2000s and 2010s.

Chemical precipitation is known to be an efficient way of improving water quality (Cooke et al., 2005; Araújo et al., 2016; Huser et al., 2016a), binding phosphorus from water and the surface layers of sediment with an added chemical. Water quality effects are immediate. The most commonly used chemical is polyaluminium chloride (Jančula \& Maršálek, 2011). The advantage of aluminium is that it retains phosphorus even in anoxic conditions, although at high $\mathrm{pH}(>8.5-9.5)$ even aluminiumbound phosphorus starts to be released (Reitzel et al., 2013).

The extensive monitoring together with the earlier management actions provided a sound basis for planning the chemical treatment. Water quality studies were complemented with sediment analyses. Different phosphorus fractions were assessed in 2012 and 2018 (Table 2), and the total phosphorus, sulphur and iron concentrations were determined in 2015. Their average contents in the $0-6 \mathrm{~cm}$ layer were $1.50 \pm 0.05$, $2.67 \pm 0.17$ and $37 \pm 0.85 \mathrm{mg} \mathrm{g}^{-1}$ dry mass, respectively $(N=6)$, resulting in Fe:P and S:Fe molar ratios of $13.5 \pm 0.38$ and $0.13 \pm 0.01$, and $\mathrm{Fe}: \mathrm{P}$ mass ratio of $24.4 \pm 0.68$ (mean $\pm \mathrm{SE}$ ).

In 2013, the lake owners decided to apply for an environmental permit to precipitate phosphorus with aluminium chloride. The permit was granted by the Regional State Administrative Agency in 2014, and it required that the effects of intensified aeration and fishing should be tested for three years before the chemical treatment. Neither of these actions produced desired results. The polyaluminium chloride PAX XL100 of Kemira Oyj was chosen as the chemical. It is a liquid containing $9 \%$ of aluminium, and widely used for purification of raw water in tap water production and treating sewage. Chemical dosing was based on the water volume in the lake, $\mathrm{pH}$, alkalinity and phosphorus fractions in sediment and water, as well as precipitation experiments. Target $\mathrm{pH}$ was $6.0-6.3$.

On 11-12 May 2017, 160 tons of polyaluminium chloride $\left(44 \mathrm{mg}^{-1}\right.$ ) of Kemira PAX XL100 were distributed all over the lake with special boats (Table 1). Although the chemical dosage was finally decided on the basis of water clarity and $\mathrm{pH}$ in precipitation experiments with Littoistenjärvi water, the amounts applied were roughly consistent with known sediment properties. In 2012, the average total $\mathrm{P}$ content in the uppermost $10 \mathrm{~cm}$ of sediment was $0.166 \mathrm{mg} \mathrm{P} \mathrm{cm}^{-3}$, the $\mathrm{HCl}$-extracted apatite-P and $\mathrm{NaOH}$-extracted $\mathrm{Fe}$ - or Al-bound $\mathrm{P}$ accounting for 15.8 and $22.8 \%$ of the total $\mathrm{P}$, respectively (Table 2 ). The remaining components were the easily extractable $\mathrm{NH}_{4} \mathrm{Cl}-\mathrm{P}(1.1 \%)$ and the residual, mostly organic P (60.2\%), part of which may be released through decomposition. When $0.87 \mathrm{~g} \mathrm{Al}$ is required to precipitate $1 \mathrm{~g}$ of $\mathrm{P}$, the precipitation of phosphorus in water (in 2006-2016 average concentration $94 \mu \mathrm{g} \mathrm{P}$ $1^{-1}$ or $304 \mathrm{~kg} \mathrm{P}$ in the whole lake) would require $2939 \mathrm{~kg}$ of PAX. Although the mobility of different sediment $\mathrm{P}$ fractions is unknown, estimates can be 
made for the potential binding of $\mathrm{P}$ to PAX after its release from sediment fractions into the porewater solution, for example during diagenesis. On this basis, a maximum estimate of 206 tons of PAX would be required to bind all other $P$ fractions in the uppermost $10 \mathrm{~cm}$ of sediment except the apatite-P, and 131 tons of PAX would be required to bind the $\mathrm{NH}_{4} \mathrm{Cl}-\mathrm{P}$, half of the NaOH-P and two-thirds of the residual P. The dosage actually applied was midway of this range.

The chemical treatment clarified water in $24 \mathrm{~h}$. For several weeks, the horizontal visibility was above $30 \mathrm{~m}$. In summer 2017 and in the open-water season of 2018, water quality was good or even excellent. The new state was stable from early July 2017 to June 2019. The change in seasonal development compared to preceding years was dramatic (Fig. 9). Internal loading of phosphorus remained low, and the typical steep increase of TP, TN and Chl- $a$, and decrease of transparency from spring to late summer disappeared. It is also informative to compare the post-treatment water quality parameter values to those observed during the whole monitoring history 1978-2018 (Fig. 4). From 2005-2016 to 2017-2018, TP declined from $92 \pm 15$ to $23 \pm 1$, TN from $1170 \pm 244$ to $320 \pm 27$, and Chl- $a$ from $45.2 \pm 19.2$ to $4.5 \pm 0.3 \mu \mathrm{g} \mathrm{l}^{-1}$ (volume-weighted averages for 1 May-15 Sep \pm SD). Transparency increased from $0.58 \pm 0.12$ to $2.22 \pm 0.01 \mathrm{~m}$, or part of the time down to the bottom as in the $1990 \mathrm{~s}$.

The chemical treatment removed all phytoplankton, but in four weeks a new assemblage developed consisting of the same species as before the treatment, with chrysophytes and diatoms as the dominants, and with few cyanobacteria. For the next two summers, phytoplankton biomass remained below the upper limit of 'good ecological status' of EU Water Framework Directive (in this lake type $<1.6 \mathrm{mg} \mathrm{l}^{-1}$ ) for the first time since the mid-1990s (Fig. 10).

Crustacean zooplankton which likewise disappeared in the treatment, recovered in about two months, and in late summer and autumn zooplankton was relatively abundant. The seasonal development of plankton in the treatment year suggests partial consumer control of phytoplankton. Phytoplankton recovered faster than crustacean zooplankton, leading to increasing turbidity in June. When the crustacean zooplankton had normalised by early July, phytoplankton decreased by two-thirds and remained below the June levels until autumn. Throughout the summer
2017, phytoplankton Chl- $a$ was inversely related to both total and herbivorous zooplankton biomass. Also the relationship between Chl- $a$ and phosphorus in late summer 2017 indicated a food chain structure capable of maintaining clear water (Fig. 11). In 2018, however, the situation was different. The ratio between zooplankton and phytoplankton was lower than in 2017, and sustained low levels of phytoplankton were likely due to low phosphorus availability.

The target $\mathrm{pH}>6$ in the chemical treatment could not be wholly fulfilled. For a short period, $\mathrm{pH}$ was about 5.5, and at some sites it even went temporarily down to below 5. As a consequence, $4940 \mathrm{~kg}$ (33 kg ha ${ }^{-1}$; about $2000 \mathrm{fish}$ ) of dead/dying big bream were collected away. Other fish survived, and test fishing did not indicate any effects attributable to the treatment. The $\mathrm{pH}$ normalised in about 2.5 weeks, after which it stayed close to 7.0 throughout the summer and autumn 2017. In summer 2018, pH gradually increased with increasing growth of submerged vegetation up to 8.4 in September, and even higher maximum was reached in 2019.

The submerged macrophytes were not directly affected by the chemical treatment, but the restored clarity of water had major indirect influence by enabling good growth of the plants, although TP levels in water were very low. In the first summer after phosphorus precipitation, the submerged plants remained as sparse as in the preceding years, in spite of clear water (Fig. 2). But during the next summer 2018, Elodea started to spread over the lake bottom, so that the coverage in late summer was approaching $30 \%$, and some other species were also increasing (Potamogeton crispus L. and Myriophyllum alterniflorum DC). Average total macrophyte biomass remained low (Fig. 2). In the following winter, oxygen deficit developed below $2 \mathrm{~m}$ depth, particularly in the southern part of the lake where the plant coverage was highest. As a result, partially decomposing floating plants appeared in spring 2019 across the lake, and were collected and transported away. Towards autumn 2019, Elodea coverage and biomass continued a moderate increase.

The TP contents of sediment after the chemical treatment did not differ significantly from the values determined before the treatment (Table 2). The loosely bound $\mathrm{NH}_{4} \mathrm{Cl}-\mathrm{P}$ fraction and the $\mathrm{HCl}-\mathrm{P}(\mathrm{Ca}-\mathrm{P})$ or insoluble apatite fraction had reduced to roughly half, and the residual phosphorus to two-thirds of the 2012 
Fig. 9 Seasonal development of total phosphorus, total nitrogen and chlorophyll $a$ concentrations, and transparency in Littoistenjärvi in 2006-2016 and in 2017-2018 (vertical broken lines $=$ date of the chemical treatment in 2017)
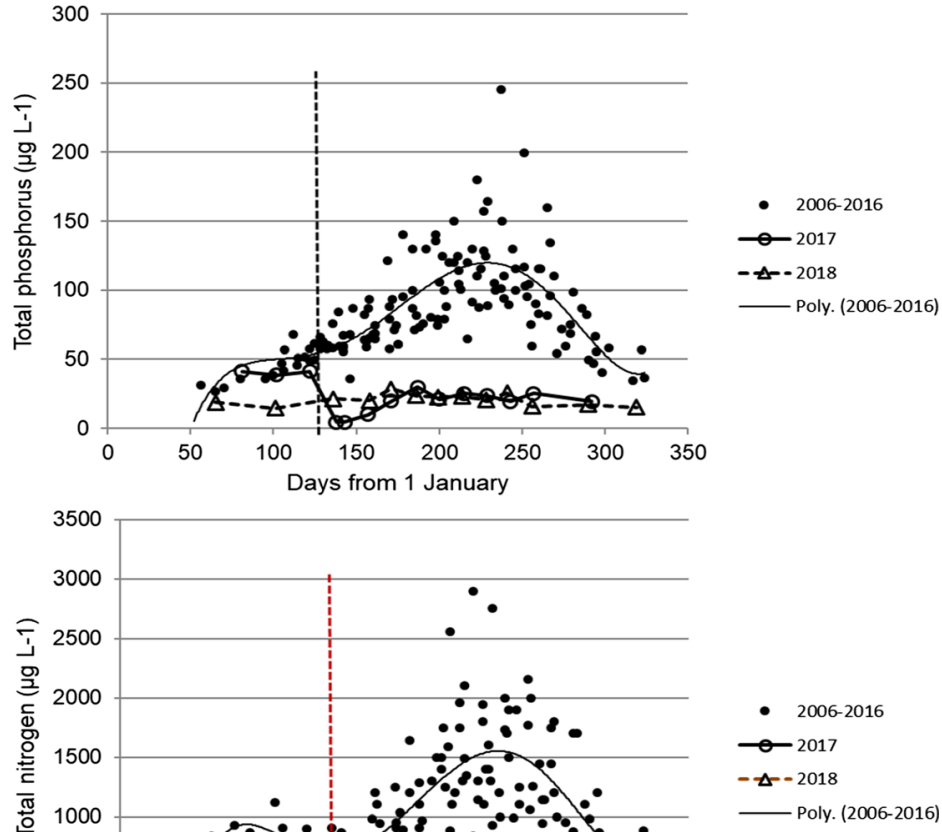

- 2006-2016

- 2017

--A-- 2018

- Poly. (2006-2016) 


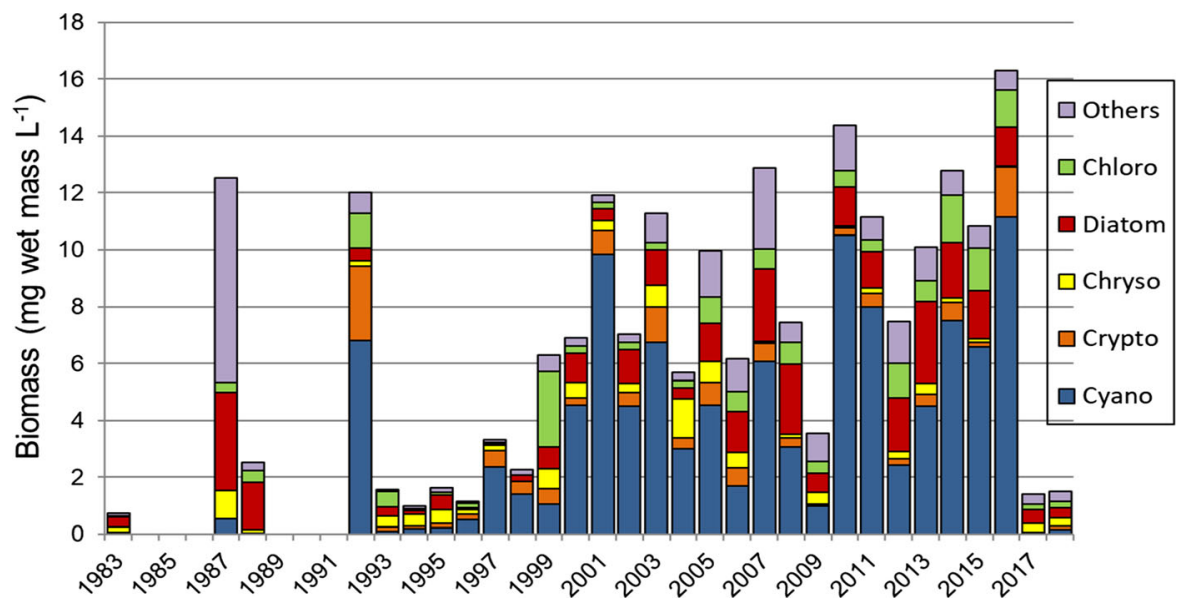

Fig. 10 Average summer (1 May-15 September) biomass of the main phytoplankton groups in Littoistenjärvi in 1983-2018

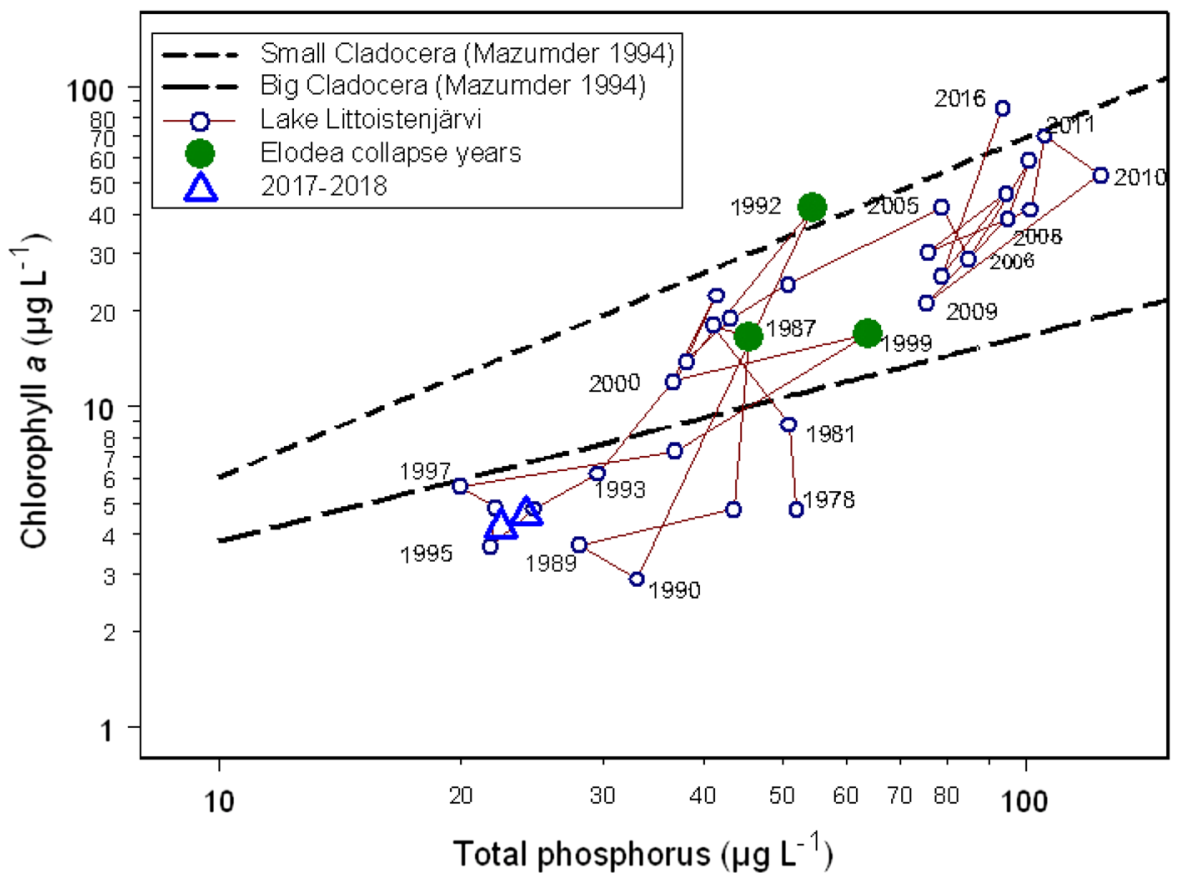

Fig. 11 Average summer (1 May-15 September) chlorophyll a concentration relative to total phosphorus in water in Littoistenjärvi in 1978-2018 (upper broken line = the relationship when planktivorous fish are abundant and zooplankton

values. The sum of the $\mathrm{Fe}$ - and Al-bound phosphorus (the BD- and $\mathrm{NaOH}$-extracted fractions) in 2018, corresponding to the NaOH-P in 2012, had doubled, and formed $44 \%$ of the total sediment phosphorus. The increase was similar throughout the uppermost $30 \mathrm{~cm}$ of sediment. In 2018, the Al-bound phosphorus comprised $69 \%$ of the sum of BD- and $\mathrm{NaOH}-\mathrm{P}$, and small-sized, lower broken line $=$ the situation with few fish and abundant large-sized zooplankton (from Mazumder, 1994), large black dots $=$ Elodea collapse years, triangles $=$ the years after chemical treatment $[2017,2018]$ )

it seems likely that the majority of the added aluminium $(14,880 \mathrm{~kg} \mathrm{Al})$ was bound with phosphorus to the sediment. The added aluminium was a minor fraction (about 1\%) of the total sediment Al.

Before the chemical treatment, the total aluminium level in water in Littoistenjärvi was on an average $101 \mu \mathrm{g} \mathrm{l}^{-1}(N=5)$. During the treatment, values 
temporarily exceeded $200 \mu \mathrm{g} \mathrm{l}^{-1}$, but they soon declined to lower level than before treatment. In summer 2019, average Al concentration was $41 \mu \mathrm{g}^{-1}$.

In the short-term, the chemical restoration of Littoistenjärvi was a great success. For the first two years, all aims were fulfilled. The nutrient concentrations declined to one-fourth and Chl- $a$ to less than onetenth of the values before the treatment. In spite of probably anoxic sediment surface in parts of the lake in winter 2019, no signs of phosphorus release from the bottom were noticed (12 February 2019: TP 9-14 $\mathrm{g} \mathrm{I} \mathrm{l}^{-1}$ at all depths). TP and Chl- $a$ remained low even in spring 2019 (23 May 2019: TP 20-22 $\mu \mathrm{g} \mathrm{l}^{-1}$, Chl- $a 3.5 \mu \mathrm{g}^{-1}$ ). In the following weeks, however, nutrients started to leak out of detached, partly dead and decomposing Elodea, floating on the lake surface, so that on 5 June 2019 TP was 21-30 $\mu \mathrm{g} \mathrm{l}^{-1}$; Chl$a$ was not yet affected (1.9-2.6 $\left.\mu \mathrm{g} \mathrm{l}^{-1}\right)$. With increasing temperature, however, an eight-week episode of turbid water followed, starting from 18 June 2019 , with elevated TP, Chl- $a$ and pH (maxima 62 and $53 \mu \mathrm{g} \mathrm{l}^{-1}$, and 9.44 , respectively), and reduced transparency (minimum $0.5 \mathrm{~m}$ ). The turbid period was preceded by an almost complete disappearance of big crustacean herbivores, suggesting that planktivorous fish were also involved. In the first weeks of turbidity, cyanobacteria increased, but soon these practically disappeared. Clear-water conditions were re-established after mid-August 2019, and prevailed still in May 2020.

Future years will show how long the good state will persist. The longevity of the results of phosphorus precipitation tends to be low in shallow lakes, particularly if the $\mathrm{Al}$ dose is $<15 \mathrm{~g} \mathrm{Al} \mathrm{m}^{-2}$ (Huser et al., 2016a). In Littoistenjärvi, the dose was as low as $10 \mathrm{~g} \mathrm{Al} \mathrm{m}^{-2}$, but the effects of the treatment might still extend over several years, because the external loading is small. Further development of the lake state is, however, crucially dependent on the behaviour of the submerged macrophytes.

\section{Discussion}

In the beginning of the study period, Littoistenjärvi was eutrophic, but from the human standpoint in rather good condition. Grazing by abundant crustacean zooplankton herbivores kept phytoplankton in check and water clear. This favourable situation changed with the increase of the invasive submerged macrophyte Elodea. During the period 1985-1999, the whole ecosystem was controlled by the cycling abundance of Elodea that peaks at every 5-7 years, followed by population collapses. Clear-water and turbid state alternated mainly because of massive nutrient release from plant biomass in crash years. Similar cycles have been reported from other lakes (Nichols \& Shaw, 1986; Rørslett et al., 1986). The reasons of the population crashes are not well understood (Simberloff \& Gibbons, 2004), but the extremely high $\mathrm{pH}$ associated with the mass occurrences may be involved. The interval between the population peaks seems to correspond to the general life cycle of the plant, in which the plant continues to grow until it reaches the water surface, and then it produces flowers and dies (Simpson et al., 1980; Rørslett et al., 1985, 1986; Nichols \& Shaw, 1986).

It is not clear why Elodea started to develop mass occurrences in the mid-1980s, having been present in the lake without problems for at least two decades. Increasing temperatures are known to speed up the growth of Elodea (Zhang et al., 2015). The air temperature in southern Finland has increased by $0.27^{\circ} \mathrm{C}$ decade $^{-1}$ (Mikkonen et al., 2014), but more important than small increases in summer temperature might be the substantial lengthening of the growing season. The duration of ice-cover in Littoistenjärvi has shortened with 60 days in 1978-2019.

The end of the macrophyte-dominated period is easier to understand. That Elodea did not recover from the 1999 crash was likely because water became turbid, and simultaneously the average water depth increased, reducing the light available for photosynthesis at the bottom. Once the turbid state was reached, internal nutrient loading kept the nutrient levels high, and the resulting low transparency hindered submerged plant growth. It is difficult to imagine a natural mechanism that could cause a shift from a turbid to a clear-water state-this requires strong external intervention.

The fluctuations of the ecosystem of Littoistenjärvi between extreme clear and turbid states in the 1990s resembled those expected from the alternative stable states hypothesis (Scheffer et al., 1993). According to this hypothesis, the ecosystem of shallow lakes has two alternative stable states: at low nutrient level a clear-water state dominated by 
submerged macrophytes, and at high nutrient level a turbid state dominated by phytoplankton. At intermediate nutrient levels both states are possible, and the shift from one state to another may be linear, nonlinear, or show hysteresis (Spears et al., 2017; Hilt et al., 2018), so that at decreasing nutrient levels the shift to clear water occurs at much lower nutrient level than the shift to turbid water under increasing nutrient levels. In the submerged plant dominated state, the plants effectively compete with phytoplankton, keeping it in check even if nutrients are abundant.

However, in Littoistenjärvi in the 1990s none of the lake's states were stable, they were clearly driven by the abundance cycles of Elodea. In the 2000s and 2010s, the situation possibly changed. The monitoring results suggest that the lake had since 2006 settled to a more or less stable phytoplankton-dominated turbid state, in which the ecological state of the lake was poor or bad. Increasing variance has been considered as one early warning signal of such critical transitions (Carpenter \& Brock, 2006; Wang et al., 2012; Gsell et al., 2016; Spears et al., 2017). In Littoistenjärvi, however, there was no such change except that, as revealed by the $\mathrm{pH}$ history, the Elodea population peaks were getting higher with time.

The decline of Elodea in 1999 led to a completely different type of ecosystem functioning. As in many other shallow lakes (Søndergaard et al., 2003), in the turbid phase of Littoistenjärvi, internal loading increased TP of water three- or fourfold during summer. This was unexpected, because the chemical requirements for retaining phosphorus in sediment were good, iron was abundant, and there was little sulphur in the top layer of sediment. Efficient binding of phosphorus by iron requires a Fe:P mass ratio $>15$ (Jensen et al., 1992) or a molar ratio > 8-10 (Hansen et al., 2003; Kleeberg et al., 2013; Bakker et al., 2016), and these ratios were clearly exceeded in Littoistenjärvi sediments. Similarly, the S:Fe molar ratio was much lower than the ratio 1.0-1.4 above which phosphorus liberation from sediments is more likely due to trapping of Fe as FeS (Rozan et al., 2002; Rothe et al., 2015). Deviations from simple chemical expectations emphasise the complexity of sediment chemistry and the importance of microbial activities.

When the internal loading was negative during the macrophyte-dominated period, all available phosphorus was immediately incorporated in the biomass of Elodea. In the turbid phase, when such a phosphorus sink did not exist, the internal loading of TP and algal blooms were associated with maximum summer temperatures, being particularly intense in the hot summers 2001, 2002, 2003, 2010 and 2014. Warming climate will therefore likely exacerbate eutrophication problems. As found in shallow Canadian lakes, extreme weather events may even lead to regime shifts (Bayley et al., 2007).

Positive feed-back loops were likely involved in the evolution of environmental conditions in Littoistenjärvi. Once the submerged vegetation had declined after 1999, phytoplankton was released from its nutrient competition, algal blooms developed, and the ensuing turbidity prevented macrophytes from recolonising deeper water. The algal blooms led to high $\mathrm{pH}$, triggering increased release of phosphorus in water, which then resulted in more algae. Another positive loop arises likewise from phytoplankton increase. Settling algae produce more readily decomposable sediment, enhancing phosphorus release back into water, to further increase phytoplankton. The recurrent population crashes of submerged macrophytes may also have led to increased accumulation of fresh organic sediment which may act as an internal phosphorus source and gradually destabilise the system (Carpenter, 1981; Hargeby et al., 2007).

Even though the increase in TP and Chl- $a$ after 1999 was gradual (Fig. 4), strong blooms of cyanobacteria started abruptly in 2000 (Fig. 10), suggesting changes in the interrelationships within the food web. Cyanobacterial blooms are often associated with high abundance of small, planktivorous fish (Hansson et al., 1998). Depending on the size structure, the same fish biomass can have very different influence on water quality (Romare \& Bergman, 1999). In southern Finland, strong year-classes of spring-spawning fish arise in warm summers (Lehtonen, 1996), resulting in a multitude of small perch, roach, ruffe (Gymnocephalus cernua [Linnaeus]), bleak (Alburnus alburnus [Linnaeus]) and bream that consume the big cladocerans, which are the most efficient algivores. Indeed, in Littoistenjärvi, zooplanktivorous small roach and perch became very abundant after the hot summer 1999, and zoobenthivorous fish, particularly bream, increased at the same time. Several similar hot summers followed in the 2000s.

These and earlier changes in food-web structure were clearly visible in the relationship between Chl$a$ and phosphorus (Fig. 11). In years before the 
submerged plant dominance, Chl- $a$ level was low relative to $\mathrm{TP}$, suggesting low abundance of planktivorous fish, and grazing control of phytoplankton by abundant large-sized herbivorous zooplankton. Low Chl- $a$-to-TP ratio prevailed through the macrophytedominated period, except for the years of Elodea collapse $(1987,1992,1999)$ which stand out with their high Chl- $a$ relative to TP. In 2000-2016, the ratio was persistently high, indicating minor role of grazers during that period, with cyanobacteria blooming every summer except 2009.

It has to be noted, however, that although low Chl$a / \mathrm{TP}$ ratios are usually thought to indicate high abundance of large-sized and efficient zooplankton grazers, low ratios can also appear for other reasons, e.g. when allelopathy by submerged macrophytes or light availability limit phytoplankton growth. Thus, although the Chl- $a-\mathrm{TP}$ relationship (Fig. 11) suggested that phytoplankton in Littoistenjärvi could from time to time be under grazing control, the ratio of the biomass of big herbivorous crustaceans to that of phytoplankton (Fig. 7) was usually very low, indicating that in most years the grazer abundance relative to phytoplankton was far too small to allow control of algae. Consistent with this, the increased crustacean zooplankton biomass in the 2000s (Fig. 6) could not prevent the water quality deterioration. Actually, zooplankton biomass showed a positive correlation with phytoplankton biomass, indicating that bottomup resource control of the food web was the rule in Littoistenjärvi. In the few years, particularly 1983 and 2009, when the zooplankton/phytoplankton ratio was clearly higher, Daphnia were abundant, the Chl-a/TP ratio and phytoplankton biomass were low, and cyanobacteria were sparse. In these years, phytoplankton may have been controlled by zooplankton grazers, although in 2009 a closer look at the Chl-aTP relationship (Fig. 11) reveals that most of the improvement of water quality was due to the lower TP, which was the result of low internal loading probably due to low temperature. In other years, there was clearly no grazing control, and the biomass of cyanobacteria could be high or low. The maintenance of the good ecological state in Littoistenjärvi might benefit from substantial reduction of the fish stock.

Besides fish, the submerged macrophytes may interfere with the positive development by growing too much in the clear water. Their photosynthesis can increase $\mathrm{pH}$ so high that aluminium-bound phosphorus may start to dissolve in water. Experiences from the Elodea-dominated period in the 1990s suggest that this risk would be low, but a real risk is leaking of phosphorus from the dying macrophytes in connection of population crashes. Mass occurrence of the submerged macrophytes was indeed developing already in the second summer after the chemical restoration of Littoistenjärvi. Invasions of nuisance submerged plants have been reported in other successfully restored lakes (Lauridsen et al., 1994; Hilt et al., 2018).

A recent review of such lake restoration cases in which submerged macrophytes were involved (Hilt et al., 2018) suggests that in-lake measures, such as biomanipulation or phosphorus precipitation, may result in completely clear water throughout the summer, but this is accompanied with rapid but transient colonisation by Ceratophyllum, Elodea or charophytes, and return to turbid conditions after some years. If this claim holds, it explains the apparent paradox concerning the significance of macrophytes to water quality. It is well established that submerged macrophytes are necessary for maintaining good water quality (Schriver et al., 1995; Søndergaard \& Moss, 1997). Yet in Littoistenjärvi, although even here submerged macrophytes were associated with clearwater conditions in most years, their excessive growth caused also problems. The key observation here is that the vegetation consisting of the invasive species Elodea and Ceratophyllum is unstable, while native species maintain more stable communities supporting permanently good water quality. The different functional roles of the individual plant species trace down to their different biological traits and growth strategies. In the same vein, species-specific characters modify the interactions between zooplankton and phytoplankton, or zooplankton and fish.

\section{Conclusions}

The case of Littoistenjärvi shows that if internal loading has become the major factor controlling water quality, the traditional restoration methods (reduction of external load, aeration, removal fishing) provide limited possibilities to improve water quality. Instead, chemical precipitation of phosphorus seems a promising measure which can break the vicious circle of algal blooms and internal loading and return the food web to 
a more balanced structure. Proper dosage is the prerequisite for successful treatment. Unfortunately, in some lakes the presence of invasive submerged macrophytes introduces uncertainty in predicting the success of restoration measures.

Acknowledgements Open access funding provided by University of Turku (UTU) including Turku University Central Hospital. Thanks are due to the numerous collaborators during the four decades of monitoring. This story of Littoistenjärvi involves the dedicated work of many persons over many years at the University of Turku and collaborating institutions (SW Finland Regional Environment Centre, SW Finland Water Protection Association, SW Finland Water and Environment Research, local municipalities, water area owners and consultants, particularly Vahanen Environment). Constructive comments by referees and the editor helped to improve the presentation. The work was funded from multiple sources. In 1992, the municipalities set up a cooperative organisation to manage the lake, Littoistenjärvi Working Group, in 2006 transformed into an official joint council (Littoistenjärven neuvottelukunta) with its own budget to monitor and manage the lake and to act as a platform for communication and collaboration between lake owners, local inhabitants, authorities and researchers. Littoistenjärvi owners' association got a strategic priority key project status and funding of the Government programme of 2015-2019 from the Ministry of Environment to improve and maintain the improved water quality, and to publish all data.

Open Access This article is licensed under a Creative Commons Attribution 4.0 International License, which permits use, sharing, adaptation, distribution and reproduction in any medium or format, as long as you give appropriate credit to the original author(s) and the source, provide a link to the Creative Commons licence, and indicate if changes were made. The images or other third party material in this article are included in the article's Creative Commons licence, unless indicated otherwise in a credit line to the material. If material is not included in the article's Creative Commons licence and your intended use is not permitted by statutory regulation or exceeds the permitted use, you will need to obtain permission directly from the copyright holder. To view a copy of this licence, visit http://creativecommons.org/licenses/by/4.0/.

Funding Funding was mainly from the municipalities of Kaarina and Lieto to University of Turku (research on the ecosystem; responsible leader JS) and to the Littoistenjärvi Working Group and Littoistenjärvi owners' association (management). Littoistenjärvi owners' association (responsible leader $\mathrm{JH}$ ) also received project funding from the Ministry of Environment for developing the management methods and disseminating information of good practices. The authors JH and JS are members of the Littoistenjärvi Working Group and the Littoistenjärvi Council.

\section{References}

Ahlgren, I., T. Frisk \& L. Kamp-Nielsen, 1988. Empirical and theoretical models of phosphorus loading, retention and concentration vs. lake trophic state. Hydrobiologia 170: 285-303.

Araújo, F., V. Becker \& J.L. Attayde, 2016. Shallow lake restoration and water quality management by the combined effects of polyaluminium chloride addition and benthivorous fish removal: a field mesocosm experiment. Hydrobiologia 778: 243-252. DOI: 10.1007/s10750-015-2606-5

Bakker, E.S., E. van Donk \& A.K. Immers, 2016. Lake restoration by in-lake iron addition: a synopsis of iron impact on aquatic organisms and shallow lake ecosystems. Aquatic Ecology 50: 121-135. DOI: 10.1007/s10452-0159552-1

Bayley, S.E., I. F. Creed, G. Z. Sass \& A. S. Wong. 2007. Frequent regime shifts in trophic states in shallow 515 lakes on the Boreal Plain: Alternative" unstable" states?. Limnology and Oceanography 52: 2002-2012.

Bengtsson, L., 1979. Chemical analysis. In Berglund, B. (ed.): Palaeohydrological changes in the temperate zone in the last 15000 years. Subproject B. Lake and mire environments. International geological correlation programme. Project 158. vol II. Specific methods. University of Lund, Lund, pp. 113-133.

Bormans, M., B. Maršálek \& D. Jančula, 2016. Controlling internal phosphorus loading in lakes by physical methods to reduce cyanobacterial blooms: a review. Aquatic Ecology 50: 407-422. DOI: 10.1007/s10452-015-9564-x

Capon, S. J., A. J. J. Lynch, N. Bond, B. C. Chessman, J. Davis, N. Davidson, M. Finlayson, P. A. Gell, D. Hohnberg, C. Humphrey, R. T. Kingsford, D. Nielsen, J. R. Thomson, K. Ward \& R. Mac Nally, 2015. Regime shifts, thresholds and multiple stable states in freshwater ecosystems; a critical appraisal of the evidence. Science of Total Environment, 534: 122-130.

Carpenter, S. R., 1981. Submerged vegetation: an internal factor in lake ecosystem succession. American Naturalist 118: 372-383.

Carpenter, S. R. \& W. A. Brock, 2006. Rising variance: a leading indicator of ecological transition. Ecology Letter 9, 311-318.

CEN, 2005. Water quality-sampling fish with multi-mesh gillnets. European Standard EN 14757:2005:E, 27 s.

CEN, 2006. Water quality-Guidance standard on the enumeration of phytoplankton using inverted microscopy (Utermöhl technique). European standard EN 15204:2006 (E).

Cooke, G. D., E. B. Welch, S. A. Peterson \& S. A. Nicholas, 2005. Restoration and Management of Lakes and Reservoirs. CRC Press, Boca Raton

Gsell, A. S., U. Scharfenberger, D. Özkundakci, A. Walters, L.A. Hansson, A. B. G. Janssen, P. Nõges, P. C. Reid, D. E. Schindler, E. Van Donk, V. Dakos \& R. Adrian, 2016. Evaluating early-warning indicators of critical transitions in natural aquatic ecosystems. PNAS 113(50): E8089E8095. DOI 10.1073/pnas.1608242113

Hamilton, D. P., N. Salmaso \& H. W. Paerl, 2016. Mitigating harmful cyanobacterial blooms: strategies for control of 
nitrogen and phosphorus loads. Aquatic Ecology 50: 351-366. DOI 10.1007/s10452-016-9594-z

Hansen, J., K. Reitzel, H.S. Jensen \& F.Ø. Andersen, 2003. Effects of aluminum, iron, nitrate, and oxygen on phosphorus release from sediment of a soft-water Danish lake. Hydrobiologia 492: 139-149.

Hansson, L-A., H. Annadotter, E. Bergman, S.F. Hamrin, E. Jeppesen, T. Kairesalo, E. Luokkanen, P-A. Nilsson, M. Søndergaard \& J. Strand, 1998. Biomanipulation as an application of food-chain theory: constraints, synthesis, and recommendations for temperate lakes. Ecosystems 1: 558-574.

Hargeby, A., I. Blindow, G. Andersson., 2007. Long-term patterns of shifts between clear and turbid states in Lake Krankesjön and Lake Tåkern. Ecosystems 10: 29-36.

Hieltes, A. \& L. Lijklema, 1980. Fractionation of inorganic phosphates in calcareous sediments. Journal of Environmental Quality 9: 405-407.

Hilt, S., M. M. Alirangues Nuñez, E. S. Bakker, I. Blindow, T. A. Davidson, M. Gillefalk, L-A. Hansson, J. H. Janse, A. B. G. Janssen, E. Jeppesen, T. Kabus, A. Kelly, J. Köhler, T. L. Lauridsen, W. M. Mooij, R. Noordhuis, G. Phillips, J. Rücker, H-H. Schuster, M. Søndergaard, S. Teurlincx, K. van de Weyer, E. van Donk, A. Waterstraat, N. Willby \& C. D. Sayer, 2018. Responses of submerged macrophyte communities to external and internal restoration measures in north temperate shallow lakes. Frontiers in Plant Science 9: 194. DOI: 10.3389/fpls.2018.00194

Hupfer, M. \& J. Lewandowski, 2008. Oxygen controls phosphorus release from lake sediments-a long lasting paradigm in limnology. Internationale Revue für Hydrobiologie 93: 415-432.

Hupfer, M., R. Gächter \& R. Giovanoli, 1995. Transformation of phosphorus species in settling seston and during early sediment diagenesis. Aquatic Sciences 57: 305-324.

Huser, B. J., S. Egemose, H. Harper, M. Hupfer, H. Jensen, K. M. Pilgrim, K. Reitzel, E. Rydin \& M. Futter, 2016a. Longevity and effectiveness of aluminum addition to reduce sediment phosphorus release and restore lake water quality. Water Research 97: 122-132. DOI: 10.1016/ j.watres.2015.06.051

Huser, B., M. Futter, J. T. Lee \& M. Perniel, 2016b. In-lake measures for phosphorus control: The most feasible and cost-effective solution for long-term management of water quality in urban lakes. Water Research 97: 142-152. DOI: 10.1016/j.watres.2015.07.036

Huttunen, I., M. Huttunen, V. Piirainen, M. Korppoo, A. Lepistö, A. Räike, S. Tattari \& B. Vehviläinen, 2016. A national scale nutrient loading model for Finnish watersheds - VEMALA. Environmental Modelling and Assessment 21: 83-109. DOI: 10.1007/s10666-015-94706

Jančula, D. \& B. Maršálek, 2011. Critical review of actually available chemical compounds for prevention and management of cyanobacterial blooms. Chemosphere 85: 1415-1422.

Jensen, H.S., P. Kristensen, E. Jeppesen \& A. Skytthe, 1992. Iron:phosphorus ratio in surface sediment as an indicator of phosphate release from aerobic sediments in shallow lakes. Hydrobiologia 235/236: 731-743.
Jeppesen, E \& I. Sammalkorpi, 2002. Lakes. In Perrow, M.R. \& A.J. Davy (eds), Handbook of ecological restoration, Volume 2: Restoration in practice: 297-324. Cambridge University Press, Cambridge

Jeppesen, E., M. Søndergaard, J. P. Jensen, K. Havens, O. Anneville, L. Carvalho, M. F. Coveney, R. Deneke, M. T. Dokulil, B. Foy, D. Gerdeaux, S. E. Hampton, S. Hilt, K. Kangur, J. Kohler, E. H. H. R. Lammens, T. L. Lauridsen, M. Manca, M. R. Miracle, B. Moss, P. Noges, G. Persson, G. Phillips, R. Portielje, S. Romo, C. L. Schelske, D. Straile, I. Tatrai, E. Willen \& M. Winder, M. 2005. Lake responses to reduced nutrient loading - an analysis of contemporary long-term data from 35 case studies. Freshwater Biol. 50, 1747-1771.

Jeppesen, E., M. Søndergaard, T. L. Lauridsen, T. A. Davidson, Z. Liu, N. Mazzeo, C. Trochine, K. Özkan, H. S. Jensen, D. Trolle, F. Starling, X. Lazzaro, L. S. Johansen, R. Bjerring, L. Liboriussen, S. E. Larsen, F. Landkildehus, S. Egemose \& M. Meerhoff, 2012. Biomanipulation as a restoration tool to combat eutrophication: recent advances and future challenges. Advances in Ecological Research 47: 411-488. DOI: 10.1016/B978-0-12-398315-2.00006-5

Jeppesen, E., M. Søndergaard \& Z. Liu, 2017. Lake restoration and management in a climate change perspective: an introduction. Water 9, 122;.DOI:10.3390/w9020122

Jeppesen, E., M. Søndergaard, M. Meerhoff, T. L. Lauridsen \& J. P. Jensen. 2007. Shallow lake restoration by nutrient loading reduction-some recent findings and challenges ahead. Hydrobiologia 584: 239-252.

Kleeberg, A., C. Herzog \& M. Hupfer, 2013. Redox sensitivity of iron in phosphorus binding does not impede lake restoration. Water Research 47: 1491-1502.

Kuha, J.K., A.H. Palomäki, J.T. Keskinen \& J.S. Karjalainen, 2016. Negligible effect of hypolimnetic oxygenation on the trophic state of Lake Jyväsjärvi, Finland. Limnologica 58: 1-6. DOI: 10.1016/j.limno.2016.02.001

Lauridsen, T. L., E. Jeppesen \& M. Søndergaard, 1994. Colonization and succession of submerged macrophytes in shallow Lake Vaeng during the first five years following fish manipulation. Hydrobiologia 275 (276): 233-242.

Lehtonen, H., 1996. Potential effects of global warming on northern European freshwater fish and fisheries. Fisheries Management and Ecology 3: 59-71.

Liljendahl-Nurminen, A., J. Horppila, T. Malinen, P. Eloranta, M. Vinni, E. Alajärvi \& S. Valtonen, 2003. The supremacy of invertebrate predators over fish-factors behind the unconventional seasonal dynamics of cladocerans in Lake Hiidenvesi. Arch. Hydrobiol. 158: 75-96.

Mackay, E.B., S.C. Maberly, G. Pan, K. Reitzel, A. Bruere, N. Corker, G. Douglas, S. Egemose, D. Hamilton, T. HattonEllis, B. Huser, W. Li, S. Meis, B. Moss, M. Lürling, G. Phillips, S Yasseri \& B. M. Spears, 2015. Geoengineering in lakes: welcome attraction or fatal distraction? Inland Waters 4: 349-356.

Marsden, M. W., 1989. Lake restoration by reducing external phosphorus loading: the influence of sediment phosphorus release. Freshwater Biology 21: 139-162.

Mazumder, A., 1994. Phosphorus-chlorophyll relationship under contrasting herbivory and thermal stratification: predictions and patterns. Canadian Journal of Fisheries and Aquatic Sciences 51: 390-400. 
Meijer, M.-L., I. de Boois, M. Scheffer, R. Portielje \& H. Hosper, 1999. Biomanipulation in shallow lakes in the Netherlands: an evaluation of 18 case studies. Hydrobiologia 408/409: 13-30.

Mikkonen, S., M. Laine, H. M. Mäkelä, H. Gregow, H. Tuomenvirta, M. Lahtinen \& A. Laaksonen, 2014. Trends in the average temperature in Finland, 1847-2013. Stochastic Environmental Research and Risk Assessment 29: 1521-1529. DOI: 10.1007/s00477-014-0992-2

Nichols, S. A. \& B. H. Shaw, 1986. Ecological life histories of three aquatic nuisance plants, Myriophyllum spicatum, Potamogeton crispus and Elodea canadensis. Hydrobiologia 131: 3-21.

Niemistö, J., H. Holmroos \& J. Horppila, 2011. Water pH and sediment resuspension regulating internal phosphorus loading in a shallow lake - field experiment on diurnal variation. Journal of Limnology 70: 3-10. DOI: 10.3274/ JL11-70-1-02

Nürnberg, G. K., M. Tarvainen, A.-M. Ventelä \& J. Sarvala, 2012. Internal phosphorus load estimation during biomanipulation in a large polymictic and mesotrophic lake. Inland Waters 2: 147-162.

Perrow, M.R., M. Meijer, P. Dawidowicz \& H. Coops, 1997. Biomanipulation in shallow lakes: state of the art. Hydrobiologia 342-343: 355-365.

Rautanen, H., J. Sarvala, E. Gustafsson, I. Isotalo, U. Laine \& J. Sainio, 1985. Littoistenjärven luonto ja käyttö (The nature of Littoistenjärvi and its use). Kaarinan-Piikkiön luonnonsuojeluyhdistys. 64 s. ISBN 951-99609-9-6. (In Finnish.)

Reitzel, K., H. S. Jensen \& S. Egemose, 2013. pH dependent dissolution of sediment aluminium in six Danish lakes treated with aluminium. Water Research 47: 1409-1420. DOI: 10.1016/j.watres.2012.12.004

Romare, P. \& E. Bergman, 1999. Juvenile fish expansion following biomanipulation and its effect on zooplankton. Hydrobiologia 404: 89-97.

Rørslett, B., D. Berge \& S.W. Johansen, 1985. Mass invasion of Elodea canadensis in a mesotrophic South Norwegian lake-impact on water quality. Verhandlungen Internationale Vereinigung für theoretische und angewandte Limnologie 22: 2920-2926.

Rørslett, B., D. Berge \& S.W. Johansen, 1986. Lake enrichment by submersed macrophytes: A Norwegian whole-lake experience with Elodea canadensis. Aquatic Botany 26: 325-340.

Rothe, M., A. Kleeberg, B. Grüneberg, K. Friese, M. PérezMayo \& M. Hupfer, 2015. Sedimentary sulphur:iron ratio indicates vivianite occurrence: a study from two contrasting freshwater systems. PLoS ONE 10(11): e0143737. DOI: 10.1371 /journal.pone.0143737

Rozan, T.F., M. Taillefert, R.E. Trouwborst, B.T. Glazer, S. Ma, J. Herszage, L.M. Valdes, K.S. Price \& G.W. III Luther, 2002. Iron-sulfur-phosphorus cycling in the sediments of a shallow coastal bay: implications for sediment nutrient release and benthic macroalgal blooms. Limnology and Oceanography 47: 1346-1354.

Ruuhijärvi, J., M. Rask, S. Vesala, A. Westermark, M. Olin, J. Keskitalo \& A. Lehtovaara, 2010. Recovery of the fish community and changes in the lower trophic levels in a eutrophic lake after a winter kill of fish. Hydrobiologia 646: 145-158. DOI: 10.1007/s10750-010-0186-y

Salmi, P., I. Malin \& K. Salonen, 2014. Pumping of epilimnetic water into hypolimnion improves oxygen but not necessarily nutrient conditions in a lake recovering from eutrophication. Inland Waters 4: 425-434. DOI: 10.5268/ IW-4.4.631

Sarvala, J. \& H. Perttula, 1994. Littoistenjärvi. Littoistenjärvityöryhmä, Kaarinan kaupunki, Liedon kunta. Kaarina 1994. ISBN 951-97062-0-8. 80 p. (In Finnish.)

Sarvala, J., H. Helminen, V. Saarikari, S. Salonen \& K. Vuorio, 1998. Relations between planktivorous fish abundance, zooplankton and phytoplankton in three lakes of differing productivity. Hydrobiologia 363: 81-95.

Sarvala, J., H. Helminen \& J. Karjalainen, 2000a. Restoration of Finnish lakes using fish removal: changes in the chlorophyll-phosphorus relationship indicate multiple controlling mechanisms. Verhandlungen Internationale Vereinigung für theoretische und angewandte Limnologie 27: 1473-1479.

Sarvala, J., A.-M. Ventelä, H. Helminen, A. Hirvonen, V. Saarikari, S. Salonen, A. Sydänoja \& K. Vuorio, 2000b. Restoration of the eutrophicated Köyliönjärvi (SW Finland) through fish removal: whole-lake vs. mesocosm experiences. Boreal Environment Research 5: 39-52.

Sas, H., 1990. Lake restoration by reduction of nutrient loading: expectations, experiences, extrapolations. Verhandlungen Internationale Vereinigung für theoretische und angewandte Limnologie 24: 247-251.

Scheffer, M. S. \& E. H. van Nes, 2007. Shallow lakes theory revisited: various alternative regimes driven by climate, nutrients, depth and lake size. Hydrobiologia 584:455-466.

Scheffer, M., S. H. Hosper, M-L. Meijer, B. Moss \& E. Jeppesen, 1993. Alternative equilibria in shallow lakes. Trends in Ecology and Evolution 8: 275-279.

Schriver, P., J. Bøgestrand, E. Jeppesen \& M. Søndergaard, 1995. Impact of submerged macrophytes on the interactions between fish, zooplankton and phytoplankton: largescale enclosure experiments in a shallow lake. Freshwater Biology 33: 255-270.

Simberloff, D. \& L. Gibbons, 2004. Now you see them, now you don't! - population crashes of established introduced species. Biological Invasions 6: 161-172.

Simpson, P. S., J. W. Eaton \& K. Hardwick, 1980. The influence of environmental factors on apparent photosynthesis and respiration of the submersed macrophyte Elodea canadensis. Plant, Cell and Environment 3: 415-423.

Søndergaard, M. \& B. Moss, 1997. Impact of submerged macrophytes on phytoplankton in shallow freshwater lakes. In Jeppesen, E., Ma. Søndergaard, Mo. Søndergaard \& K. Christoffersen. (eds), The structuring role of submerged macrophytes in lakes. Ecological Studies, vol 131: 115-132. Springer-Verlag, New York.

Søndergaard, M., J.P. Jensen \& E. Jeppesen, 2003. Role of sediment and internal loading of phosphorus in shallow lakes. Hydrobiologia 506-509: 135-145.

Søndergaard, M., R. Bjerring \& E. Jeppesen, 2013. Persistent internal phosphorus loading during summer in shallow eutrophic lakes. Hydrobiologia. 710: 95-107.

Søndergaard, M., E. Jeppesen, T. L. Lauridsen, C. Skov, E. H. van Nes, R. Roijackers, E. Lammens \& R. Portielje, 2007. 
Lake restoration: successes, failures and long-term effects. Journal of Applied Ecology 44: 1095-1105.

Spears, B. M., L. Carvalho, M. N. Futter, L. May, S. J. Thackeray, R. Adrian, D. G. Angeler, S. J. Burthe, T. A. Davidson, F. Daunt, A. S. Gsell, D. O. Hessen, H. Moorhouse, B. Huser, S. C. Ives, A. B. G. Janssen, E. B. Mackay, M. Søndergaard \& E. Jeppesen, 2016. Ecological Instability in Lakes: A Predictable Condition? Environmental Science \& Technology 50: 3285-3286. DOI: 10.1021/ acs.est.6b00865

Spears, B. M., M. N. Futter, E. Jeppesen, B. J. Huser, S. Ives, T. A. Davidson, R. Adrian, D. G. Angeler, S. J. Burthe, L. Carvalho, F. Daunt, A. S. Gsell, D. O. Hessen, A. B.G. Janssen, E. B. Mackay, L. May, H. Moorhouse, S. Olsen, M. Søndergaard, H. Woods \& S. J. Thackeray, 2017. Ecological resilience in lakes and the conjunction fallacy. Nature Ecology \& Evolution 1: 1616-1624.

Steinman, A. D. \& B. M. Spears (eds), 2020. Internal phosphorus loading in lakes. Causes, case studies, and management. J. Ross Publishing. Fort Lauderdale, 460

Visser, P.M., B.W. Ibelings, M. Bormans \& J. Huisman, 2016. Artificial mixing to control cyanobacterial blooms: a review. Aquatic Ecology: 50: 423-441. DOI: 10.1007/ s10452-015-9537-0
Wahlberg, A., 1913. Bidrag till kännedomen om Littois-träsk med särskild hänsyn till dess plankton. Acta Soc. Fauna Flora Fennica 38: 1-201.

Wang, R., J. A. Dearing, P. G. Langdon, E. Zhang, X. Yang, V. Dakos \& M. Scheffer, 2012. Flickering gives early warning signals of a critical transition to a eutrophic lake. Nature 492, 419-422.

Zamparas, M. \& I. Zacharias, 2014. Restoration of eutrophic freshwater by managing internal nutrient loads: a review. Science of the Total Environment 496: 551-562. DOI: 10.1016/j.scitotenv.2014.07.076

Zhang, X., R. Odgaard, B. Olesen, T. L. Lauridsen, L. Liboriussen, M. Sondergaard, Z. Liu \& E. Jeppesen, 2015. Warming shows differential effects on late-season growth and competitive capacity of Elodea canadensis and Potamogeton crispus in shallow lakes. Inland Waters 5: 421-432. DOI: $10.5268 / \mathrm{IW}-5.4 .830$

Publisher's Note Springer Nature remains neutral with regard to jurisdictional claims in published maps and institutional affiliations. 